\title{
カンキツ類の化学成分とがん予防物質に関する研究
}

$$
\text { 十一元 晴 }
$$

\section{Chemical Study of Citrus Plants in the Search for Cancer Chemopreventive Agents}

\author{
Motoharu JU-ICHI \\ School of Pharmaceutical Sciences, Mukogawa Women's University, \\ 9-11-68, Koshien, Nishinomiya 663-8179, Japan
}

(Received November 30, 2004)

\begin{abstract}
The constituents of Citrus plants were investigated to develop useful agents that are effective in cancer chemoprevention. We examined the roots and bark of the roots of various Citrus plants, resulting in the isolation of many novel compounds. Their structures were determined using spectroscopic methods, especially 2D-NMR spectra. The following new compounds of constituents were found: dimeric coumarins, dimeric acridone alkaloids, and acridone-coumarin dimers. Auraptene and nobiletin are known as useful constituents of the peel of Citrus plants for cancer chemoprevention. However, we found that $3,5,6,7,8,3^{\prime}, 4^{\prime}$-heptamethoxyflavone (HPT) has both antitumor promotion and initiation activities and is more effective than auraptene and nobiletin. We synthesized pentaallyl quercetin (QPA), a useful antitumor compound that has the additional effects of a P-glycoprotein (P-gp) inhibitor. The inhibitory effects of QPA on P-gp were more effective than those of the typical P-gp inhibitors cyclosporin A and verapamil. Both HPT and QPA have antitumor promotion activity and are potential candidates for effective multidrug resistance agents in cancer chemotherapy.
\end{abstract}

Key words - Citrus constituents; cancer chemoprevention; dimeric coumarin; dimeric acridone alkaloid; acridonecoumarin; flavone

\section{1. はじめに}

カンキツ類に由来する生薬として「陳皮」，「青 皮」,「枳実」,「枳殼」,「橙皮」,「仏手柑」などがあ り，中国では「橘紅」，「香円」，「橘核」，「橘絡」な ぞもある. 西洋医学では，一般に健胃薬に分類され るが，中医学及び漢方医学では臨床上それぞれを区 別して駆風，去痰，鎮咳，排膿などにも用いられて いる.

果実の含有成分として，精油成分やフラボノイド 配糖体及び塩基性成分が知られていたが，近年，ポ リメトキシフラボン類やクマリン類が多数報告さ れ, 抗潰瘍, c-AMP Phosphodiesterase 阻害, 抗ア レルギー，抗炎症，鎮痛などの生物作用を有するも のが発見されている。しかし，生薬として用いられ

武庫川女子大学薬学部（６663-8179 西宮市甲子園九番 町 11-68)

e-mail: mjuichi@mwu.mukogawa-u.ac.jp 本総説は，平成 15 年度宮田記念学術論文賞の受賞を記 念して記述したものである.
る品種は，ごく一部に限られている.

筆者らがカンキツ類成分の研究を開始した頃は, 輸入の自由化や嗜好の変化からカンキツの価格が暴 落し, 多量・多種の栽培品種が放置されたり, 焼却 処分されるものが急増し，これらを何とか活用した いと考えたのが発端である。 また，アクリドンアル カロイドの 1 つである acronycine が抗がん剤とし て臨床試験に付されていた。 その頃，カンキツ類の 根，根皮部にもアクリドンアルカロイドが含有され ていることが分かり，制がん効果を持つ化合物が見 出されることが期待された。ささらに，果実部の成分 に関しては多数の報告があつたが，根皮，根部に関 する報告は，ほとんど皆無に近かった，その原因と して，カンキツ類の栽培品種は接木によるものがほ とんどであり，特に根・根皮部を研究材料とするこ とは種の同定に大いに問題があり，難しい状況であ ったことが挙げられる。幸いなことに，日本におけ るカンキツ類の遺伝子資源の保存のために純系種を 栽培している農林水産省果樹試験場（現独立行政法 
人農業技術研究機構果樹研究所カンキツ研究部）興 津支場では数年周期で古い木を処分しており，それ らを提供頂けることになった。そこで，制がん物質 を求めて, カンキツ類の根皮・根部及び果実部の成 分検索を実施することにした。

ところで，化学発がんには，少なくとも 2 つ過 程，すなわちイニシエーションとプロモーションと いう機構が関与し，それぞれの過程にイニシエー ターとプロモーターと呼ばれる化学物質が関与して いることが明らかになっている。これらの過程を阻 止できる化合物が見出せれば「がん予防」の有力な 武器になり得る。伊藤らによって確立された TPA に対する Epstein-Barr virus 活性化抑制効果を指標 にしたスクリーニング法 ${ }^{1,2}$ は，微量かつ多種類の 試料を短期間に検定することが可能である．本法を 用いた活性試験について京都府立医科大学生化学教 室の御協力を頂けることになり，生物活性の検定に も目途がついた。

活性物質を探索する過程において，多数の新規ク マリン，アクリドンアルカロイド，フラボノイド類 を単離し，それらの構造を明らかにした。特に，全 く新しい型の多数の二量体化合物の構造を決定し,

ヘテロ環化学の新しい分野を開拓することができ た。また，発がん予防物質として有望な 3,5,6,7,8, $3^{\prime}, 4^{\prime}$-heptamethoxyflavone を見出すとともに，本化 合物をリード化合物として入手が容易な quercetin から誘導した 3,5,7,3', $4^{\prime}$-pentaallylflavone が発がん 予防に有効であるとともに薬物排出に関わる $\mathrm{P}$ - 糖 たんぱく質阻害作用を有することを見出した．以下 にそれらの研究成果について述べる。

\section{2. カンキツ類根部・根皮部に含まれる新規化合} 物

研究材料として次のカンキツ類を用いた。 ハッサ ク (Citrus hassaku Hort. ex. TANAKA), グレープフ ルーツ (C. paradisi MACF.)，マーシュグレープフ ルーツ (C. paradisi MACF.)，ユコウ（C. yuko Hort. ex. TANAKA)，エトログシトロン (C. medica L. var. ethrog ENGL), ナッダイダイ (C. natsudaidai HAYATA），川野ナツダイダイ（C.natsudaidai HAYATA), ヤラハ [C. paradisi MACF. (Dunkan grapefruit) $\mathrm{x} C$. tangerina Hort. ex. TANAKA (Dancy tangerine)], サンボウカン (C. sulcata Hort. ex. TAKAHASHI), キクダイダイ (C. cana- riculata Hort. ex. TANAKA), バレンシアオレンジ (C. sinensis OSBECK), 文旦 (C. grandis OSBECK $\mathrm{f}$. buntan HAYATA), 平戸文旦 (C. grandis OSBECK $\mathrm{f}$. HIRADO), 舟床 (C. funadoko Hort. ex. TANAKA), ヤラハ [Citrus paradisi MACF. (ダンカングレープ フルーツ) x C. tangerina Hort. ex. TANAKA（Dancy tangerine)], 黄金柑 (C. flaviculpus Hort. ex. TANAKA)，プメロ (Pummelo) [C. grandis OsBECK cv. May Pummelo x C. paradisi MACF. (マー シュグレープフルーッ， ルミー（C. lumia Risso), キノクニ (C. kinokuni Hort. ex. TANAKA) 及びユズ（C. junos TANAKA）。また交雑育成種で ある [C. paradisi MACF. (duncan) x C. sinensis OsBECK（ハムリン)], [Okitsu No. 17 x C. tamurana TANAKA（日向夏)], [Okitsu No17: unnamed selection $C$. tamurana TANAKA. (日向夏) x $C$. sinensis L. OSBECK cv. FuKUHARA (スウィートオレンジ)], [C. tamurana Hort. ex. TANAKA (日向夏) x $C$. kinokuni Hort. ex. TANAKA（ヒラキツ)], [ハッサ ク (C. hassaku Hort. ex. TANAKA) x C. grandis (平戸文旦) $],[C$. flaviculpus Hort. ex. TANAKA （黄金相）x C. tamurana Hort. ex. TANAKA（日向 夏) ], [Swingle Citrumelo (Poncirus trofoliata $\mathrm{x} C$. paradisi) $],[C$. unshiu MARC. (宮川早生) $\mathrm{x} C$. sinensis OSBECK（toropita orange）］（清見） x C. iyo Hort. ex. TANAKA（伊予)], 及び [C. paradisi MACF. (ダンカングレープフルーツ) x C. sinensis OSBECK（ハムリン)] についても含有成分を検索し た.

抽出にはアセトンを用い，得られたエキスを酸性 部，塩基性部に分液処理することなく，セライトに 吸着させ，そのままシリカゲルカラムクロマトに付 した。 さらにカラム，遠心クロマトを繰り返し行 い，最終的には分取薄層クロマトにより分離した. 主として得られた化合物は多数の新規化合物を含む クマリン及びアクリドンアルカロイドであった。分 液操作を行った過去の研究では，アクリドンアルカ ロイドが単離されなかったのは，このタイプの化合 物の弱塩基一塩基性なしという特異な性質によるも のと思われる.

本論文では多数の二量体クマリン，二量体アクリ ドンアルカロイド，アクリドンアルカロイドークマ リン及び特異な構造のアクリドンアルカロイドに限 
定して紹介する.

これらの構造決定は, 主として二次元 NMR スペ クトル特に HMQC や HMBC を使用した。一部の 新規骨格や珍しい結合形態を有する化合物の構造決 定は X 線結晶解析も合わせ行った。

2-1. クマリン二量体 多数の新規二量体クマ リンを単離したが，それらは2つのクマリン環の連 結様式すなわち炭素-炭素結合，エーテル結合，フ ラン環やピラン環を形成して連結された型及び Diels-Alder 付加した型の 4 種に分類できる.

2-1-1. 炭素-炭素結合による二量体

2-1-1-1. ピラン環ーピラン環—Bisclausarin (1), Yukomarin (2) Bisclausarin (1) の PMR は，クマリン環 4 位の水素のシグナル 1 個，オレフ イン水素 1 個， 2 個の 1,1- ジメチルアリル基及び 1 個の 2,2- ジメチルピラン環の存在を示した。また, MS から判明した分子式に反して PMR, CMR で単 量体に相当するシグナルのみ観測されたことから, 完全に対称な構造が推定された。また，O-メチル 体のメトキシ基からオレフィン水素に NOE が観測 されたことからリニア型のクマリン骨格の存在が判 明し, clausarin (3) がピラン環部分で対称型に二 量化した構造と推定し，HMBCによる炭素-水素の 相関により構造を確定した. ${ }^{3)}$ また，yukomarin（2) は種々のデータから二量体クマリンと推定され，そ の PMR はクマリン骨格の 3,4- 位及び 4 位の水素,

3 個の 1,1- ジメチルアリル基， 2 個の 2,2- ジメチル ピラン環の存在を示し, HMBCによりピラノクマ リン環の間で連結していることが判明した。ピラン 環の型式及び構造の確定は O- メチル体の 2 つのメ トキシ基を照射すると，双方ともに 4 位の水素とピ ラン環のベンジル位水素に NOE が観測された。し たがって 2 つピラン環はリニア型であること，す なわち yukomarin は clausarin (3) と nordentatin (4) で構成されていることが証明できた. ${ }^{4)}$

2-1-1-2. ジヒドロピラン環ージヒドロピラン環 Bishassanidin (5) Bishassanidin（5）は, PMR スペクトルにより水素結合した水酸基 1 個, 4 位の水素，1,1- ジメチルアリル基 2 個，2,2- ジメ チルピラン環の存在が示唆された。分子量からクマ リン単量体が完全に対称に二量化した構造が推定さ れた。既知の hassanidin（6）のデータと比較検討 し 2,2- ジメチルピラン環部分で二量化した構造と
決定した. 5$)$

2-1-1-3. ジヒドロピラン環-ラクトン環—Bisnorponcitrin (7) Bisnorponcitrin (7) の PMR スペクトルにおいて，クマリン環の 3,4- 位及び 4 位の水素，2,2- ジメチルピラン環オレフィン水素 1 組，1,1- ジメチルアリル基が 2 個，隣接したメチン 一メチレン水素の存在が判明した。 また，分子量か ら二量体と推定されたが，ピラン環部分の型式，2 つのクマリン核の結合位置はメチル体で検討した。

O-メチル体のメトキシ基を照射すると，一方から は 4 位及びオレフィン水素に, 他方からは 4 位とメ チン水素にNOE が観測された。 したがって 2 つの クマリンはリニア型のピラノクマリンである norponcitrin（nordentatin）（4）が二量化した化合物で あり，その結合位置は 3 位とジヒドロジメチルピラ ン環のベンジル位と判明した。 ${ }^{5)}$

2-1-1-4. ジヒドロピラン環-芳香環—Nordenletin (8) Nordenletin（8）の PMR スペクトル において，クマリン環 3,4- 位の水素に基づくシグ ナルが 2 組観測されたことから，非対称の二量体と 推定された。また，1,1- ジメチルアリル基，2,2- シ メチルピラン環，2,2- ジメチルジヒドロピラン環の 存在も明らかとなった。 O-メチル体の 2 つのメト キシ基を照射すると, 一方からは 4 位の水素とオレ フィン水素に, 他方からは 4 位の水素とベンジル位 のメチンに NOE が観測されたことから，リニア型 ピラノクマリン xanthoxyletin（9）の demethyl 体の 8 位と nordentatin (4) のジヒドロ体のジヒドロピ ラン環のベンジル位で二量化した構造が判明した (Chart 1).6)

2-1-1-5. ピラン環メチルの間—Biseselin（10) Biseselin（10）の構造は, PMR スペクトルからク マリン骨格に特徵的な 3,4,5,6- 位及び 2,2- 置換ピ ラン環オレフィン水素 2 個の存在が判明した。残り のメチル基 1 個とメチレン基 1 個のシグナルについ ては，分子式と合わせ考察し 2 つの seselin（11）が メチレンーメチレンで連結した珍しい構造であるこ とが判明した. ${ }^{4)}$

\section{2-1-2. エーテル結合による二量体}

2-1-2-1. Khellactone とピラノクマリンKhelmarin-A (12), -B (13), -C (14), -D (15) cisKhellactone（16）のベンジル位の水酸基がリニア型 ピラノクマリンである nordentatin (4), xanthoxyle- 


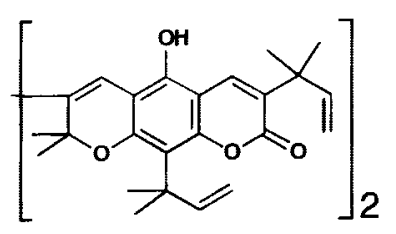

bisclausarin (1)

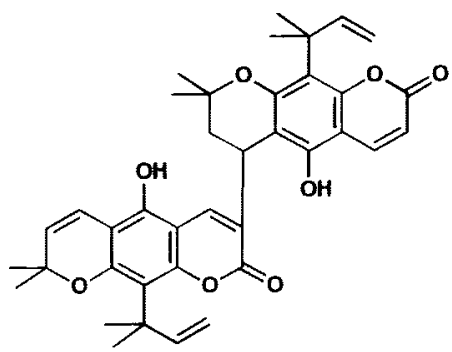

bisnorponcitrin (7)<smiles>C=CC(C)(C)c1cc2c(O)c3c(c(C(C)(C)C=C)c2oc1=O)OC(C)(C)C(C1=Cc2c(c(C(C)(C)C=C)c4oc(=O)ccc4c2O)OC1(C)C)=C3</smiles>

yukomarin (2)

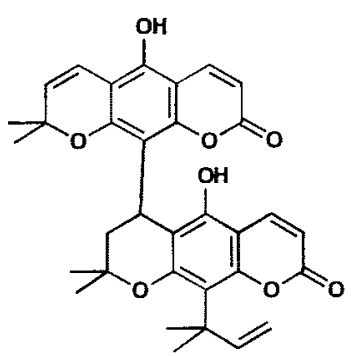

nordenletin (8)<smiles>C=CC(C)(C)c1cc2c(O)c3c(c(C(C)(C)C=C)c2oc1=O)C1(C)CCCC2C(C3=O)C2(C)O1</smiles>

bishassanidin (5)<smiles>[R2]c1cc2c([Y9])c3c(c([R2])c2oc1=O)OC(C)(C)C=C3</smiles>

clausarin (3) $\mathrm{R}_{1}=\mathrm{R}_{2}=\mathrm{DMA}, \mathrm{R}_{3}=\mathrm{OH}$ nordentatin (4) $\mathrm{R}_{1}=\mathrm{R}_{2}=\mathrm{H}, \mathrm{R}_{3}=\mathrm{OH}$ xanthoxyletin (9) $\mathrm{R}_{1}=\mathrm{R}_{2}=\mathrm{H}, \mathrm{R}_{3}=\mathrm{OCH}_{3}$<smiles>C=CC(C)(C)c1cc2c(O)c3c(c(C(C)(C)C=C)c2oc1=O)OC(C)(C)CC3=O</smiles>

hassanidin (6)

Chart 1

tin (9), clausarin（3） あるいはアンギュラー型ピラ ノクマリン seselin (11) とエーテル結合した二量体 である. Khellactone 部の立体化学は酸素の付け根 の水素間の NOE 及びそれらの結合定数から決定で きた。 また，2つの環の結合位置もベンジル位の水 素と他方のピラノクマリンの水素の間に観測される NOE から決定した. ${ }^{5,7,8)}$

2-1-2-2. ピラノクマリン芳香環—Marshdimerin（17）リニア型クマリンが芳香環の間でエー テル結合した唯一の例である.PMR において 4 位 の水素と推定できるシグナル 2 個がシングレットと して観測されることから，3 位に置換基の存在する クマリンの二量体と推定された。 また，4個の1,1ジメチルアリル基， 2 個の 2,2- ジメチルピラン環の 存在も判明した. HMBCによる炭素一水素の相関か らピラン環はともにリニア型であり，2つのクマリ ン環の 3 位に 1,1- ジメチルアリル基の存在するこ とが明らかとなったささらにCMR において 4 個の 1,1- ジメチルアリル基の $s p^{3}$ 炭素のシグナルのうち 1 個だけが著しく低磁場に出現していることから,

1 個は O- 置換体, 残りの 3 個は C- 置換体と考えら れた，2つのクマリン核の結合位置は，4 位の水素 を照射したときに，NOEが観測されるアリル水素
が 2 個と 1 個であり，したがつて 2 つのクマリン核 の結合位置は 2 つの clausarin（3）の 5 位とその O-1,1- ジメチルアリルエーテル体の 8 位との間で エーテル酸素で連結していることが決定した (Chart 2). 9)

\section{2-1-3. 環形成による二量体}

2-1-3-1. シクロブタン環—Bisosthenon（18）， Bisosthenon-B (19) Bisosthenon（18）の PMR, $\mathrm{CMR}$ データは, 分子量から予測される数の半分を 示すことから完全に対称な構造が推定された。ま た，メチン水素間に NOEが観測されたことから osthenon（20）が head-to-head 又は head-to-tail 型 にシクロブタン環を形成して二量化した構造が推定 された. シクロブタン環上の置換基位置, 立体配置 の決定には種々の方法が提案されているが，いずれ も決定的な手段ではない。幸い良好な結晶が得られ たので X 線結晶解析を行った. ${ }^{9-11)}$ 推定した構造と は異なり，嵩高いクマリン環部分がシスに配置する 構造であることが分かり, 全く新しい型の化合物の 構造決定には, 絶対的な証明の必要性を痛感させら れた. Bisosthenon-B（19）は各種スペクトルデー タから osthenon（20）の対称な二量体と判明した. 構造が確定している bisosthenon（18）の PMR デー 
<smiles>CC(C)(C)C1(C)C=Cc2c(ccc3ccc(=O)oc23)O1</smiles>

biseselin (10)<smiles>C=CC(C)(C)Oc1c2cc(C(C)(C)C=C)c(=O)oc2c(OC(C)(C)C=C)c2c3c(c(C(C)(C)C=C)cc12)C=CC(C)(C)O3</smiles>

marshdimerin (17)<smiles>[Z3]c1cc2c(OC3c4c(ccc5ccc(=O)oc45)OC(C)(C)C3O)c3c(c([Z13])c2oc1=O)OC(C)(C)CC3</smiles>

khelmarin-A (12) $\mathrm{R}_{1}=\mathrm{H}, \mathrm{R}_{2}=\mathrm{DMA}$

khelmarin- $B$ (13) $\mathrm{R}_{1}=\mathrm{R}_{2}=\mathrm{H}$

khelmarin-C (14) $\mathrm{R}_{1}=\mathrm{R}_{2}=\mathrm{DMA}$<smiles>CC1(C)C=Cc2c(ccc3ccc(=O)oc23)O1</smiles>

seselin (11)<smiles>CC1(C)C=Cc2c(cc(OC3c4c(ccc5ccc(=O)oc45)OC(C)(C)C3O)c3ccc(=O)oc23)O1</smiles>

khelmarin-D (15)

Chart 2

夕との比較から両者では 1 つのメチン水素のケミカ ルシフトが異なるだけであり，NOE の測定によ り, シクロブタン環上の 4 つの水素が trans, cis, trans と判明し構造を決定した. ${ }^{9}$

2-1-3-2. ジヒドロフラン環——urobinordentatin (21), Furobiclausarin (22) Furobinordentatin（21）は MS, PMR, CMR データから 1,1- ジメ チルアリル基とジメチルピラン環を有する 2 つのク マリンの二量体と推定された。 O,O'- ジメチル化体 の NOE 測定により 2 つヒピラノクマリンはリニヤ 型で，そのピラン間部分で二量化した構造が推定さ れた。また，4つのメチン水素間に相互に NOE が 観測されたこと，HMBC により炭素一水素間の相関 を詳細に検討した結果，ピラノクマリンである nordentatin（4）が cis, trans, trans の立体配置のテ トラヒドロフラン環を介して二量化した構造が判明 した。本化合物は未知の新しい骨格を有しており, 最終的には X 線結晶解析を行い, その構造を確定 した. ${ }^{12)}$

また，furobiclausarin（22）に関しては PMR, CMR デー夕を furobinordentatin（21）のそれらと
比較した結果，両化合物は類似した構造であること が判明した。顕著な相違点はクマリン環に特徴的な 水素のうち 3 位のシグナルが認められないこと, 1,1- ジメチルアリル基のシグナルが 2 個分見られる ことである。したがって，それぞれのクマリン環 3 位に 1,1- ジメチルアリル基を持つ構造を推測した。 HMBC スペクトル，NOE を詳細に検討した結果， テトラヒドロフラン環部分の構造は単量体である clausarin (3) が furobinordentatin（21）の場合と同 様に cis, trans, trans の立体配置のテトラヒドロフ ラン環を介して二量化した構造と決定した（Chart 3). ${ }^{12,13)}$

2-1-3-3. ピラノピラン環—Claudimerin-A (23), Claudimerin-B (24) Claudimerin-A (23) は PMR スペクトルにおいて，クマリン環の 4 位の 水素がシングレットに現われ，2 個の 1,1- ジメチル アリル基の存在が判明した. 残りの 2 つのメチン水 素とメチル基の間に観測された NOE 及び $\mathrm{J}$ 值から 2,2- ジメチルジヒドロピラノクマリン環の存在が推 定できた．PMRにおいてクマリン単量体に相当す るシグナルしか観測されなかったこと，EI-MS に 
<smiles>COc1ccc2ccc(=O)oc2c1[C@@H]1[C@H](OC)[C@@H](OC)[C@H]1c1c(OC)ccc2ccc(=O)oc12</smiles>

bisosthenon (18)

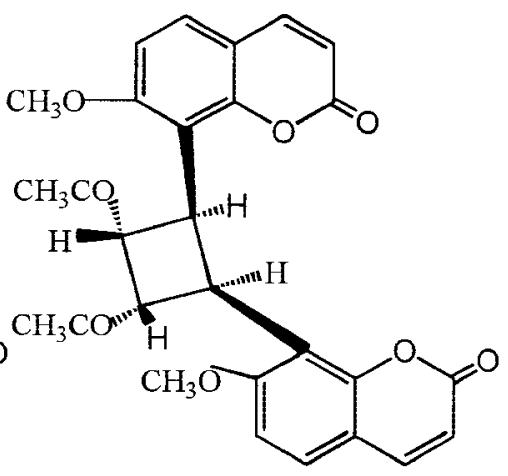

bisosthenon-B (19)<smiles>COc1ccc2ccc(=O)oc2c1/C=C/C(C)=O</smiles>

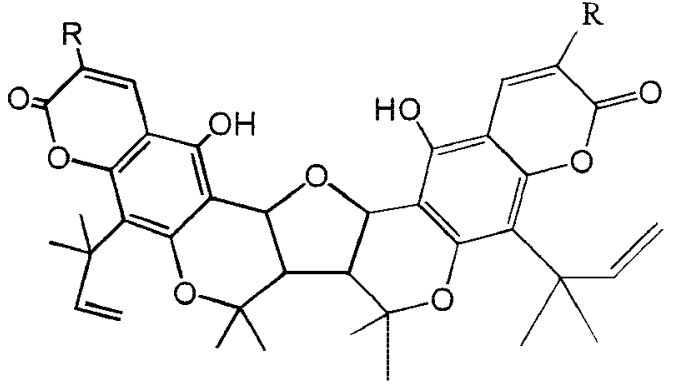

furobinordentatin (21) $\mathrm{R}=\mathrm{H}$ furobiclausarin (22) $\mathrm{R}=\mathrm{DMA}$

osthenon (20)

Chart 3

おいて, 分子イオンピークの半分に強いフラグメン トイオンが見られたことから，本化合物はジヒドロ ピラノクマリンが完全に対称に結合した構造を推定 した．HMBCの検討により 1,1- ジメチルアリル基 は 3 及び 8 位に存在し, 構成する単量体クマリンは clausarin（3）であり，その二量体と推定できた.

しかし，2 個のクマリン骨格の結合様式及び全構造 に関しては，スペクトルデータによるこれ以上の解 析が困難であり, 未知の全く新しい骨格の存在が考 えられたので X 線結晶解析を行った。 その結果, ピラノピラン環を介して二量化した構造が判明し た. ${ }^{14,15)}$ また, claudimerin-B（24）は種々のスペク トルデータの比較により claudimerin-A のピラノピ ラン環部分に関する立体異性体と推定できた。ピラ ノピラン環部分の 4 つの水素の結合定数が比較的大 きいこと，またすべてのシグナル間で NOE が観測 されたことから, trans-trans-trans 又は cis-trans-cis のいずれかの立体配置をとることが推定された.

PMR における結合定数から trans-trans-trans が妥 当と考えられ，NOESY スペクトルによっても支持 された. しかし, 他の立体配置の可能性も否定でき ず，立体構造は未確定である. ${ }^{15)}$

2-1-3-4. ピラン環—Citrumarin-A (25)， -B (26), -C (27), -D (28), -E (29) いずれもリニア 型ピラノクマリンともう 1 つのクマリン骨格が新た
にジヒドロピラン環を形成して連結した構造をして いる，連結部の構造については，酸素が置換した炭 素に結合した 3 個の 4 級メチル基，メチレンーメチ ンーメチレン水素の関係を HMBC スペクトルの詳 細な検討により決定した。Citrumarin-A（25）は nordentatin (4) と trans-dehydroosthol (30), citrumarin-B は nordentatin ( 4 ) と trans-dehydroosthenol (31), citrumarin-C は nordentatin (4) と trans-des-O-methylcitrubuntin (32), citrumarin-D (28) は nordentatin (4) と cis-des-O-methylcitrubuntin （33）が連結した構造である. Citrumarin-E（29） だけが，リニア型クマリン clausarin（3）を構成分 子とし, trans-dehydroosthenol (31) との間でピラ ン環を形成している (Chart 4). 16)

2-1-4. Diels-Alder 付加体一 Hassmarin (34), Bisparasin（36）既知の二量体クマリンとしては 最も一般的な型であるが, カンキツ類からは 2 種が 単離できた。 Hassmarin (34) は O-demethyl-phebalosin (35) と trans-dehydroosthol (30) が, bisparasin（36）は citrubuntin（37）と trans-dehydroosthol（30）が環状付加した構造を有している. ク マリン環炭素と連結部水素に関しては HMBCによ る相関, さらに立体化学は NOEにより決定し た. ${ }^{17,18)}$ 連結部にモノテルペン単位を持つ二量体ク マリンは知られているが, hassmarin はモノテルペ 


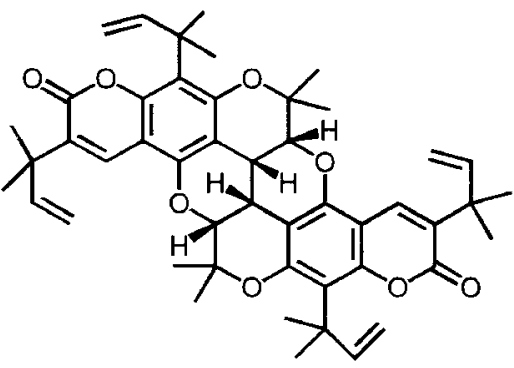

claudimerin-A (23)<smiles></smiles>

citrumarin-A (25) $\mathrm{R}_{1}=\mathrm{CH}_{3}, \mathrm{R}_{2}=\mathrm{H}$ citrumarin- $\mathrm{B}$ (26) $\mathrm{R}_{1}=\mathrm{OH}, \mathrm{R}_{2}=\mathrm{H}$ citrumarin-E (29) $\mathrm{R}_{1}=\mathrm{CH}_{3}, \mathrm{R}_{2}=\mathrm{DM} \Lambda$<smiles></smiles>

claudimerin-B (24)

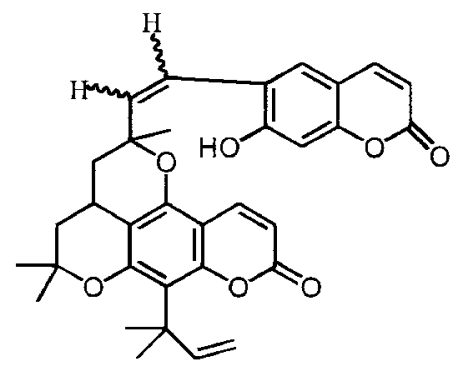

(E) citrumarin-C (27)

(7) citrumarin-D (28)<smiles>[R]c1cc2ccc(=O)oc2c([R9])c1[R20]</smiles>

(30) $\mathrm{R}_{1}=\mathrm{H}, \mathrm{R}_{2}=\mathrm{Me}, \mathrm{R}_{3}=>$

(31) $\mathrm{R}_{1}=\mathrm{H}, \mathrm{R}_{2}=\mathrm{H}, \mathrm{R}_{3}=$

(32) $\mathrm{R}_{1}=\ldots, \mathrm{R}_{2}=\mathrm{R}_{3}=\mathrm{H}$

(33) $R_{1}=$ , $\mathrm{R}_{2}=\mathrm{R}_{3}=\mathrm{H}$<smiles></smiles>

hassmarin (34)<smiles></smiles>

bisparasin (36)<smiles>C=C(C)C1OC1c1c(O)ccc2ccc(=O)oc12</smiles>

O-demethyl phebalosin (35)

Chart 5

ン部とともにエーテル結合を持つた最初の例である (Chart 5).

2-2. アクリドンアルカロイド二量体Ｃitbismine と命名した一連の新しい二量体アクリドンア ルカロイド citbismine-A (38), -B (39), -C (40), -D (41) , -E (42), -F (43) を単離した。これまでに知ら れていた Glycosmis 属植物から得られた Glycobismines-A, -D,-Eでは，一方のアクリドン部のカテ コール型水酸基が他方のアクリドン部のプレニル基 側鎖と 1,4-dioxide 型に結合している。それらに対
し，カンキツ類から得られた citbismine 類では，ヒ ドロキシイソプロピルフラン環を持つフラノアクリ ドンアルカロイド furofoline-II (44) の誘導体のジ ヒドロフラン環と他のアクリドンアルカロイドが結 合している。それらの構造は, 種々のスペクトル デー夕の解析, 最終的には citbismine-A (38) のX 線結晶解析により確定した。 ${ }^{19)}$ 構成成分は, furofoline-II の dihydro-5-hydroxy 体と natuscitrine-II (45), citpressine-II（46）の結合体がそれぞれ citbismine-A ${ }^{19,20)}$ 及び citbismine-F, ${ }^{22)}$ furofoline-II $の$ di- 
hydro-6-hydroxy-5-methoxy 体と natuscitrine-II (45), citpressine-II (46), citracridone-I (47) 及び citpressine-I（48）の結合体がそれぞれ citbismine$\mathrm{B}$, citbismine- $\mathrm{C},{ }^{20)}$ citbismine-D 及び citbismine- $\mathrm{E}^{21)}$ である。また， bis-5-hydroxynoracronycine (49) と 命名した 5-hydroxynoracronycine（50） の二量体を 単離した。本化合物の構造は 5-hydroxynoracronycine を酸と処理して合成した標品との比較により構 造決定した (Chart 6). ${ }^{23)}$

\section{2-3. アクリドンークマリン二量体}

2-3-1. Acrimarine クマリンの 1 種である suberosin（51）が種々のアクリドンアルカロイドと 二量化した一連の化合物を acrimarine と命名し, acrimarines-A- $\mathrm{N}$ の 13 種 (-C と-L の同一性が判 明したため）の構造を明らかにした. ${ }^{24-28)}$ クマリ ンの結合部位は，アクリドン骨格の 4 位であるもの が 2 種 [acrimarine-C (54), acrimarine-D (55)], そ の他の 11 種はすべて 2 位であり，他の部位で結合 した化合物は未発見である。構造決定は，PMR ス ペクトルにおいて容易に帰属できるアクリドン骨格 とクマリン骨格のシグナルのほかに，特徴的に出現
する $85.5-6.5$ 付近のベンジル位とオレフィン水素 の 2 つの doublet シグナル, CMR スペクトルにお ける $\delta 32-35$ (singlet, ベンジル炭素)，123-126 (doublet，オレフィン炭素)，132-136 (singlet，オ レフィン炭素）付近に観測される 3 つのシグナルか らアクリドン部とクマリン部の連結部分の構造は決 定できた。置換位置は suberosin 部分のメトキシ基 からの NOE により決定し，HMBC により確定し た (Chart 7).

2-3-2. Neoacrimarine Suberosin 以外の 3 環 性クマリンと種々のアクリドンアルカロイドとの二 量体 11 種を単離し, neoacrimarines-A--K と命名 し構造決定した。これらは, クマリン骨格の違いに より 3 種類の型に分類できる.

（1）アクリドンーリニア型 3 環性クマリン型：4 種 [neoacrimarines-A (65), -B (66), -D (67), -E (68) ] 28-30) クマリン部分は clausarin (3) 又は nordentatin (4) の 2 種で構成され, アクリドンとク マリン骨格を結ぶ炭素-炭素結合の位置は，アクリ ドン骨格の 2 位のものが 1 種（neoacrimarine-D) , 4 位のものが 3 種である. 4 位にクマリンが炭素-炭

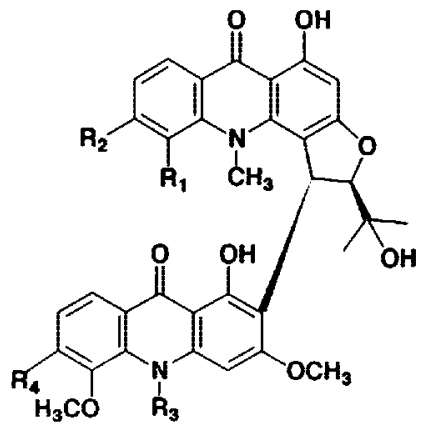

citbismine $A$ (38) $R_{1}=O H, R_{2}=R_{3}=H, R_{4}=O C H_{3}$ citbismine-B (39) $\mathrm{R}_{1}=\mathrm{OCH}_{3}, \mathrm{R}_{2}=\mathrm{OH}, \mathrm{R}_{3}=\mathrm{H}, \mathrm{R}_{4}=\mathrm{OCH}_{3}$ cilbismine-C (40) $\mathrm{R}_{1}=\mathrm{OCH}_{3}, \mathrm{R}_{2}=\mathrm{OH}, \mathrm{R}_{3}=\mathrm{CH}_{3}, \mathrm{R}_{4}=\mathrm{OCH}_{3}$ citbismine-E (42) $\mathrm{R}_{1}=\mathrm{OCH}_{3}, \mathrm{R}_{2}=\mathrm{OH}, \mathrm{R}_{3}=\mathrm{CH}_{3}, \mathrm{R}_{4}=\mathrm{OH}$ citbismine- $F$ (43) $\mathrm{R}_{1}=\mathrm{OH}, \mathrm{R}_{2}=\mathrm{H}, \mathrm{R}_{3}=\mathrm{CH}_{3}, \mathrm{R}_{4}=\mathrm{OCH}_{3}$<smiles>[R]c1cc(O)c2c(=O)c3ccc(OC)c(OC)c3[nH]c2c1</smiles>

natsucitrinc-I (85) $\mathrm{R}=\mathrm{OH}$ natsucitrine-II (45) $\mathrm{R}=\mathrm{OCH}_{3}$<smiles>Cn1c2ccccc2c(=O)c2c(O)cc3oc(C(C)(C)O)cc3c21</smiles>

furofoline-II (44)

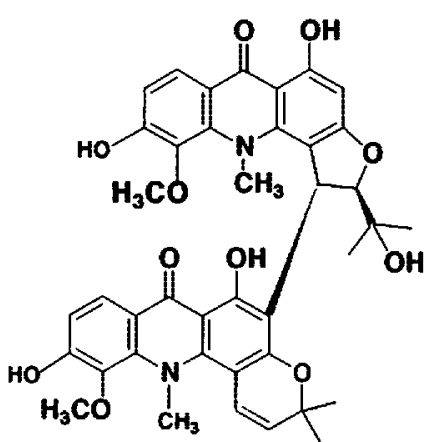

citbismine-D (41)

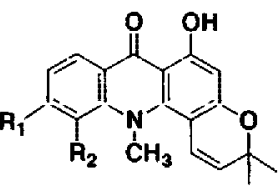

citracridone-1 (47) $\mathrm{R}_{1}=\mathrm{OCH}_{3}, \mathrm{R}_{2}=\mathrm{OH}$

citracridone-III (87) $\mathrm{R}_{1}=\mathrm{R}_{2}=\mathrm{OH}$

5-hydroxynoracronycine (50) $\mathrm{R}_{1}=\mathrm{OH}, \mathrm{R}_{2}=\mathrm{H}$

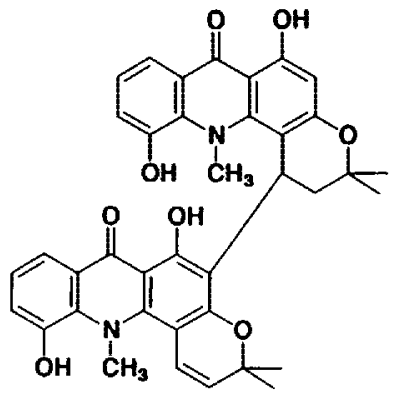

bis-5-hydroxynoracronycine (49)<smiles></smiles>

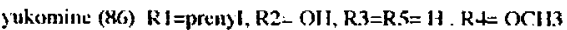
citpressine -1 (48) $\mathrm{R} 1=\mathrm{R} 3=\mathrm{H}, \mathrm{R} 2=\mathrm{R} 4=\mathrm{OCl} 3, \mathrm{R} 5=\mathrm{OH}$ citpressine-II (46) RI=R3-H. R2-R4=R.5=OCH3 prenytcitpressine (84) R 1-H, R2=R5=OH, R3-prenyi , $\mathrm{R}+\mathrm{t}=\mathrm{OCH}$

citnusaminc (88) $\mathrm{R} 1=\mathrm{R} 3=\mathrm{R} 5=\mathrm{H}, \mathrm{R} 2=\mathrm{OCH} 3, \mathrm{R}+\mathrm{OH}$ citrusinine-II (82) R1=R5=H, R2=R4=OH, R3=OCH3 pummeline (83) $\mathrm{R} 1=\mathrm{R} 3=\mathrm{R}+=[1, \mathrm{R} 2$ : $\mathrm{OCl} \mathrm{i}, \mathrm{R}=\mathrm{OH}$

Chart 6 
<smiles>[R6]c1ccc2c(=O)c3c(O)c([R6])c([R6])c([R])c3n([Z7])c2c1[R5]</smiles>

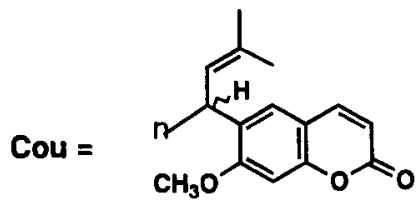

\begin{tabular}{|c|c|c|c|c|c|c|}
\hline & R1 & R2 & R3 & R4 & R5 & R6 \\
\hline acrimarine-A (52) & $\mathrm{CH}_{3}$ & Cou & $\mathrm{OH}$ & $\mathrm{H}$ & $\mathrm{OCH}_{3}$ & $\mathrm{OCH}_{3}$ \\
\hline acrimarine-B (53) & $\mathrm{H}$ & Cou & $\mathrm{OCH}_{3}$ & H & $\mathrm{OCH}_{3}$ & $\mathrm{OCH}_{3}$ \\
\hline acrimarine-C (54) & $\mathrm{H}$ & H & $\mathrm{OCH}_{3}$ & Cou & $\mathrm{OCH}_{3}$ & $\mathrm{OH}$ \\
\hline acrimarine-D (55) & H & $\mathrm{H}$ & $\mathrm{OCH}_{3}$ & Cou & $\mathrm{OCH}_{3}$ & $\mathrm{OCH}_{3}$ \\
\hline acrimarine-E (56) & $\mathrm{H}$ & $\mathrm{Cou}$ & $\mathrm{OCH}_{3}$ & $\mathrm{H}$ & $\mathrm{OCH}_{3}$ & $\mathrm{OH}$ \\
\hline acrimarine-F (57) & $\mathrm{CH}_{3}$ & Cou & $\mathrm{OCH}_{3}$ & $\mathrm{H}$ & $\mathrm{OCH}_{3}$ & $\mathrm{OH}$ \\
\hline acrimarine-G (58) & $\mathrm{CH}_{3}$ & Cou & $\mathrm{OH}$ & $\mathrm{H}$ & $\mathrm{OH}$ & $\mathrm{H}$ \\
\hline acrimarine-H (59) & $\mathrm{CH}_{3}$ & Cou & $\mathrm{OCH}_{3}$ & $\mathrm{H}$ & $\mathrm{OH}$ & $\mathrm{H}$ \\
\hline acrimarine $=I(60)$ & $\mathrm{CH}_{3}$ & Cou & \multicolumn{2}{|c|}{ dimethylpyran } & $\mathrm{OH}$ & $\mathrm{H}$ \\
\hline acrimarine-J (61) & $\mathrm{CH}_{3}$ & Cou & \multicolumn{2}{|c|}{ dimethylpyran } & $\mathrm{OCH}_{3}$ & $\mathrm{OH}$ \\
\hline acrimarine-K (62) & $\mathrm{CH}_{3}$ & Cou & $\mathrm{OH}$ & $\mathrm{H}$ & $\mathrm{OCH}_{3}$ & H \\
\hline acrimarine-M (63) & $\mathrm{CH}_{3}$ & Cou & $\mathrm{OH}$ & $\mathrm{H}$ & H & $\mathrm{H}$ \\
\hline acrimarine-N (64) & $\mathrm{CH}_{3}$ & Cou & $\mathrm{OCH}_{3}$ & H & $\mathrm{OCH}_{3}$ & $\mathrm{OCH}_{3}$ \\
\hline
\end{tabular}

Chart 7
素結合している場合は, acrimarine の場合も含めて アクリドンはすべて N-H 体である．2つの骨格の 結合位置は, HMBCによりジヒドロピラン環のべ ンジル位水素と炭素の相関を検討して決定した。 ま た，O-メチル体のメトキシ基からのクマリン環 4 位水素, ジヒドロピラン環のベンジル位水素への NOE が観測されたことから, クマリン部分のリニ ア型を証明した。

(2) アクリドンーアンギュラー 3 環性クマリン 型：6種 [neoacrimarines-C (67), -F (70), -G (71), -H (72)，-I（73），-J (74) ] 30-32) クマリン部分は cis-khellactone（16）で，すべてアクリドン骨格の 5 位とエーテル結合している．PMR スペクトルにお けるケラクトンのジメチルピラン環の酸素の付け根 の水素, ジメチル基のシグナルから, 結合部分の構 造が推定できた。アクリドンとクマリン両環の結合 位置は HMBC におけるケラクトンのベンジル位水 素との相関から決定した。 なお，ケラクトン部分の 立体化学についてはメチレンプロトンの $\mathrm{J}$ 值, 相互 に観測されるNOE から相対配置を決定した。

(3) アクリドンーフラノクマリン型 : 1 種 [neoacrimarine-K (75) ] ${ }^{32) \quad シ ゙ ヒ ト ゙ ロ フ ラ ノ ク マ リ ~}$ ン環を有する唯一の例である. PMR 及び CMR か ら 3- 置換 -2- ヒドロキシイソプロピルジヒドロフ ラン環の存在が判明した。 アクリドン環との結合位 置は HMBC によるベンジル位の水素と炭素の相関
により決定した（Chart 8).

2-3-3. Dioxinoacrimarine-A アクリドンアル カロイドークマリン二量体のうち, benzo-1,4dioxane 環を介して二量化している新骨格の化合物 を初めて単離し, dioxinoacrimarine-A（76）と命名 した.PMR スペクトルより 7,8- 置換クマリン骨格, 4-メトキシ -5,6-二置換アクリドン骨格の存在が判 明した．2つの骨格間に介在するトランス型オレフ イン水素, メチル基, メチレン水素の結合様式は HMBC スペクトルによる相関から結合位置並びに 相対位置を決定した. ${ }^{8,28)}$ Benzo-1,4-dioxane 環を介 して二量化していると推定される同様の化合物も単 離し, 種々のスペクトルを用いて検討しているが, 位置異性が未決定になっている。

\section{2-4. 特異な構造を有するアクリドンアルカロイ} ド

2-4-1. アクリドンーリグナンリグナン部分構 造を有するアクリドンアルカロイドである，1,4- シ オキサン環を形成して結合しているアクリドンとリ グナン部分の相関関係について種々のスペクトル法 を用いて検討した。しかし，リグナン部のベンジル 位の水素がアクリドン部の 5 位あるいは 6 位の酸素 とエーテル結合した 2 通りの位置異性の決定が $\mathrm{HMBC}$ などの 2 次元 NMR を駆使しても困難であ つた。現在までのところ良好な結晶が得られた acrignine-A（77）のみが X 線結晶解析によって構 


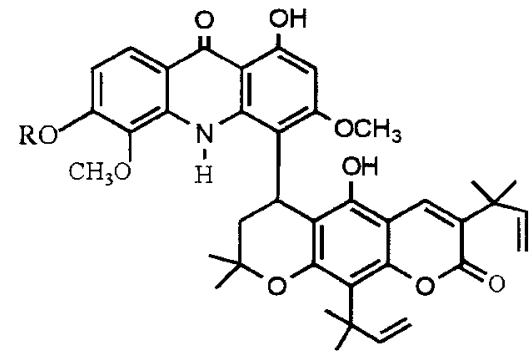

neoacrimarine- $\mathrm{A}(65) \mathrm{R}=\mathrm{CH}_{3}$ neoacrimarine- $\mathrm{B}(66) \mathrm{R}=\mathrm{H}$<smiles>[R]c1ccc2c(=O)c3c(O)cc4c(C5c6c(ccc7ccc(=O)oc67)OC(C)(C)[C@@H]5O)c3n(C)c2c1OC1C=CC(C)(C)OC41</smiles><smiles></smiles>

neoacrimarine-D (68) neoacrimarine- $\mathrm{C}(67) \mathrm{R}=\mathrm{OH}$ neoacrimarine- $\mathrm{H}(72) \mathrm{R}=\mathrm{H}$
neoacrimarine-E (69)

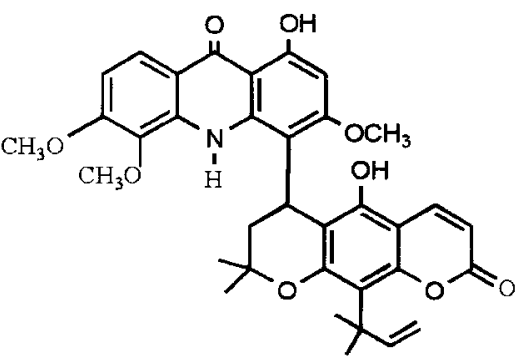

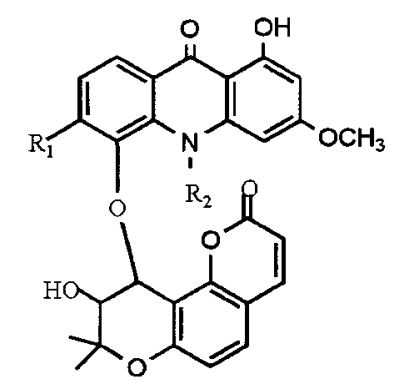

neoacrimarine- $\mathrm{F}(70) \mathrm{R}_{1}=\mathrm{OH}, \mathrm{R}_{2}=\mathrm{CH}_{3}$ neoacrimarine- $\mathrm{G}$ (71) $\mathrm{R}_{1}=\mathrm{H}, \mathrm{R}_{2}=\mathrm{CH}_{3}$ neoacrimarine-I (73) $\mathrm{R}_{1}=\mathrm{OCH}_{3}, \mathrm{R}_{2}=\mathrm{H}$ neoacrimarine-J (74) $\mathrm{R}_{1}=\mathrm{OH}, \mathrm{R}_{2}=\mathrm{H}$

neoacrimarine-K (75)

Chart 8

造決定済み ${ }^{33)}$ であるが，残る化合物の構造は未決定 である.

\section{2-4-2. シトロポン 7 員環部分を持つアクリ} ドンアルカロイド citropone-A （78），-B（79），-C （80）を初めて単離した. Citropone-A の PMR ス ペクトルにおいて, 通常のアクリドンアルカロイド より分子内水素結合した水酸基のシグナルが 1 個多 く，低磁場に特徵的に観測される芳香環プロトンが $\delta 7.97,6.67$ （各 $1 \mathrm{H}, \mathrm{d}$ ）に $\mathrm{J}=12.7 \mathrm{~Hz}$ の大きなカ ップリングで観測されることから新規骨格の存在が 推測された。 HMBCにおける相関から 7 員環部を 有する構造が推定されたが，最終的には X 線結晶 解析を行って決定した. ${ }^{34)}$ 関連する citropone-B 及 び -C の構造は各種スペクトルデータを citroponeA のそれらと比較検討して構造を明らかにした. ${ }^{35)}$ トロポロン型の 7 員環の部分構造を有しているのに ちなんでシトロポンと命名した。

2-4-3. アザクリドン 6 員環部分の 1 つがピ
リジン環になった azacridone-A（81）を初めて単離 した．通常のアクリドンアルカロイドの PMR スペ クトルでは観測されない $\delta 9.19(1 \mathrm{H}, \mathrm{s}), 8.54,8.06$ $(1 \mathrm{H}, \mathrm{d}, \mathrm{J}=4.9 \mathrm{~Hz})$ の著しく低磁場のシグナルは, それらのケミカルシフト, J 值から 3,4- 置換ピリジ ン環の水素と決定した. ${ }^{36}$

アザ型アクリドンアルカロイドは合成品の例はあ つたが，天然物として得られたのは最初の例であ り，また，6位が窒素であるアザアクリドンとして は唯一の例である (Chart 9).

2-5. アクリドンアルカロイドの抗発がんプロ モーション活性Ｂerenblum らによる発がん多段 階の提唱以来, 化学物質によって発生するがんは, イニシエーション フプロモション フプログレッシ ヨンの過程で発生・進行するものと考えられてい る.37) イニシエーション段階は短期間，非可逆的で あるのに対し, プロモーション段階は長期間を必要 とし，可逆的であることから，プロモーション過程 
<smiles></smiles>

dioxinoacrimarine-A (76)

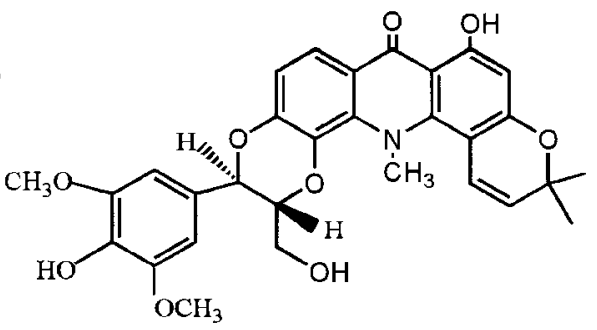

acrignine-A (77)

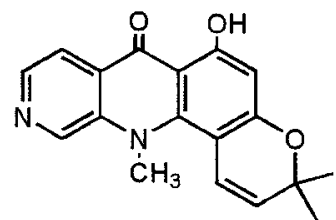

azacridone-A (81)

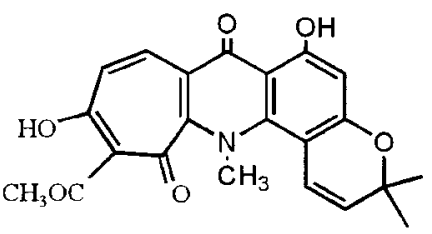

citropone-A (78)

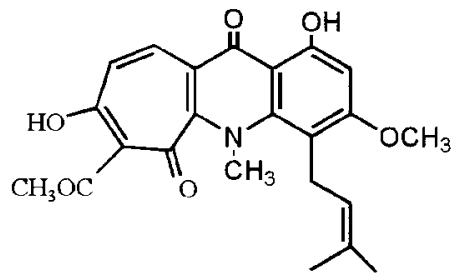

citropne-B (79)

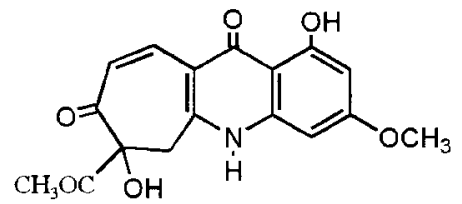

citropne-C (80)

Chart 9

の阻害剂を開発することが，「がんの化学予防」に 最も効果的な手段と見なされている.この 2 段階目 に作用する化合物は「発がんプロモーター」と呼ば れており，12-O-tetradecanoylphorbol-13-acetate （TPA）はその代表的な化合物である.

筆者らは，伊藤らにより確立された短期簡易検定 法である TPAによる Epsein-Barr virus (EBV) 活 性化抑制作用を指標にしたスクリーニング法 ${ }^{1,2)}$ 用いて単離成分の活性を検討した。なお，この試験 により EBV-EA 産生を抑制した化合物はin vivoに おいても活性を有することが多く, 抗発がんプロ モーターとなり得ると考えられている。実験は, EBV ゲノムを保有する Raji 細胞を n- 酪酸存在下 発がんプロモーターである TPA とともに培養し,

$\mathrm{EBV}$ 活性化により強く誘導産生される早期抗原 （EA）を間接蛍光抗体法により検出し細胞の数を測 定した。活性の評価は，TPA 及び n- 酪酸のみを加 えた陽性コントロール群（約 30\%の細胞に EBVEA が観測される）と，検体を加えた系との EBVEA 発現率の比較により行った. 細胞自身の生存率 （細胞毒性）については，2-3 日の通常培養条件に おける細胞の自然死率が 10 - $20 \%$ であことか ら, 試薬・検体などを加えて処理した細胞 (2 日後) の生存率が $60 \%$ 以上であれば細胞毒性は弱いもの と判断した.
比較的多く単離できた単量体及び二量体のアクリ ドンについて EBV 発現抑制試験を行つた。いずれ の化合物も $1000 \mathrm{~mol} \mathrm{ratio} / \mathrm{TPA} の$ 高濃度でも細胞 毒性は弱かった。 単量体のアクリドンアルカロイド では citrusinine-II (82), pummeline (83), prenylcitpressine (84), 5-hydroxynoracronycine (50), 二量体 アクリドンクマリンでは試験に付した acrimarine のすべて, neoacrimarines-A (65), -B (66), -E (69)

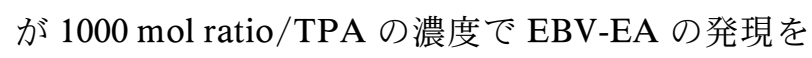
100\%抑制した。特に 5-hydroxynoracronycine（50), neoacrimarine-A (65), -G (71) は $10 \mathrm{~mol} \mathrm{ratio/TPA}$ の濃度でも 10 - $13 \%$ の抑制活性を示した。したが って，これらの化合物は抗発がんプロモーターとし て有望な化合物と考えられる。 また, natsucitrine-I

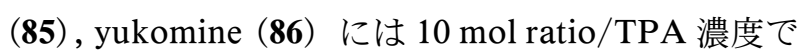
も，それぞれ $10 \%, 17 \%$ の抑制効果が認められ た。 ${ }^{38)}$ 各濃度で良好な活性を示した citpressine-I (48), -II (46), citracridone-I (47), -III (87), yukomine (86), citrusamine (88) も細胞毒性の弱い, 抗 発がんプロモーターとして期待できる（Table 1a, Table 1b).

構造と活性の関係について考察すると, 次の傾向 が認められた。 1）フェノール性水酸基の影響 : 5 位又は 6 位に水酸基を持つ化合物は, これらの位置 に水酸基を持たない化合物に比べて強い活性が見ら 
Table 1a. Relative Ratio of Activation with respect to Positive Control

\begin{tabular}{|c|c|c|c|c|}
\hline \multirow{3}{*}{$\begin{array}{c}\text { Sample } \\
(\text { TPA } 32 \mathrm{pmol}=100 \%)\end{array}$} & \multicolumn{4}{|c|}{ Concentration (mol ratio/TPA) } \\
\hline & 1000 & 500 & 100 & 10 \\
\hline & \multicolumn{4}{|c|}{$\%$ to control (\% viability) } \\
\hline Citpressine-I & $24.2(80)$ & $42.4(>80)$ & 78.9 & 100 \\
\hline Citpressine-II & $28.3(70)$ & 50.5 & 80.9 & 100 \\
\hline Citracridone-I & $6.0(70)$ & 34.4 & 77.8 & 92.9 \\
\hline Citracridone-II & $36.7(80)$ & 68.0 & 83.7 & 93.5 \\
\hline Citracridone-III & $19.2(50)$ & 55.7 & 75.4 & 97.8 \\
\hline Natsucitrine-I & $8.4(80)$ & 21.7 & 52.4 & 89.5 \\
\hline Natsucitrine-II & $36.8(80)$ & 68.3 & 92.7 & 100 \\
\hline Citrusinine-II & $0 \quad(80)$ & 61.6 & 80.1 & 100 \\
\hline Grandisine-II & $23.3(70)$ & 50.8 & 100 & 100 \\
\hline Glycocitrine-I & $12.0(80)$ & 68.3 & 100 & 100 \\
\hline Grandisinine & $27.2(80)$ & 48.5 & 90.1 & 100 \\
\hline Yukomine & $33.7(70)$ & 35.7 & 80.2 & 82.6 \\
\hline Citramine & $53.6(80)$ & 71.6 & 100 & 100 \\
\hline Pummeline & $0 \quad(70)$ & 33.1 & 90.6 & 100 \\
\hline Buntanine & $23.9(20)$ & $93.1(60)$ & 100 & 100 \\
\hline Honyumine & $14.8(50)$ & $51.2(60)$ & 87.0 & 100 \\
\hline Prenylcitpressine & $0 \quad(60)$ & 50.1 & 86.4 & 100 \\
\hline Citrusamine & $11.3(70)$ & 26.7 & 72.7 & 93.5 \\
\hline 5-hydroxynoracronycine & $0 \quad(70)$ & 20.2 & 49.4 & 87.8 \\
\hline 5-methoxynoracronycine & $57.2(60)$ & 67.0 & 100 & 100 \\
\hline 1, 3-dihydroxy-N-metylacridone & $27.7(80)$ & 52.3 & 82.1 & 92.6 \\
\hline 1-hydeoxy-3-methoxy-N-metylacridone & $17.9(70)$ & 64.4 & 91.8 & 100 \\
\hline 1-hydroxy-3-acetoxyacridone & $30.2(80)$ & 76.6 & 100 & 100 \\
\hline 1,3-diacetoxyacridone & $21.8(80)$ & 50.8 & 94.0 & 100 \\
\hline Acrimarine-F & $0 \quad(50)$ & $0 \quad(50)$ & $47.7(80)$ & 66.8 \\
\hline Acrimarine-B & $10.0(80)$ & 44.3 & 65.8 & 88.2 \\
\hline Acrimarine-D & $31.7(70)$ & 72.1 & 100 & 100 \\
\hline
\end{tabular}

Table 1b. Relative Ratio of Acridone-Coumarin Dimers Activation with respect to Positive Control

\begin{tabular}{lcccc}
\hline \multirow{2}{*}{$\begin{array}{c}\text { Sample } \\
\text { (TPA 32 pmol=100\%) }\end{array}$} & \multicolumn{4}{c}{ Concentration (mol ratio/TPA) } \\
\cline { 2 - 5 } & \multicolumn{4}{c}{ \% to control (\% viability) } \\
\hline Neoacrimarine-A & $0 \quad(70)$ & 44.2 & 80.3 & 100 \\
Neoacrimarine-B & $0(70)$ & 41.7 & 77.2 & 95.6 \\
Neoacrimarine-C & $4.6(60)$ & 59.8 & 85.0 & 100 \\
Neoacrimarine-D & $9.0(60)$ & 60.9 & 86.7 & 100 \\
Neoacrimarine-E & $0 \quad(60)$ & 48.7 & 79.9 & 100 \\
Neoacrimarine-F & $8.4(60)$ & 61.5 & 88.0 & 100 \\
Dioxinoacrimarine-A & $12.5(60)$ & 63.7 & 89.2 & 100 \\
Glycyrrhetic acid & $15.6(70)$ & 54.3 & 100 & 100 \\
\hline
\end{tabular}

れる. また， 5 位に水酸基を持つピラノアクリドン は強い活性を示す．2）2,2- ジメチルピラン環を持 つアクリドンアルカロイドでは活性を有するものが
認められるが，それらにおいてはアンギュラー型の 方がリニア型より活性が強い。 3）アクリマリン類 は，それらを構成する単量体のアクリドンアルカロ 
イドより活性が強い，4）アクリドン骨格の 2 位に クマリン部が置換した acrimarine-B（53），-F（57） の方が 4 位にクマリン部が置換した acrimarine-D （55）よりも活性が強い。構造と活性の相関に関し てはさらなるデータの蓄積が必要であり，また，in vivoでの活性も未検討である.

\section{3. カンキツ果実に含まれるがん予防物質}

1990 年アメリカがん学会は「がん予防に役立つ 食物」のガイドライン ${ }^{39)}$ を発表したが，その推奨す る食品をピラミッドで表した中で，カンキツ類は中 位にランクされている。 また，日本でも 1996 年生 研機構のプロジェクトの 1 つとして「カンキッによ るがん予防に関する基礎的研究」が発足した．果実 部の研究に着手することには，多くの先人の数多く の研究により多種・多数のクマリンやフラボノイド の存在が報告されており，さらにカンキツ類に含ま れる抗発がんプロモーターとして aurapten $(\mathbf{8 9}),{ }^{40)}$ 及び nobiletin $(\mathbf{9 0})^{41)}$ が知られていたので大きなた めらいがあった。しかし，活性を指標とした分離が 行われていなかったので，新しい発見の可能性を期 待して活性物質の探索に着手した。

3-1. 活性品種の選定農林水産省果樹試験場 （現独立行政法人カンキツ研究部）興津支場で栽培 されたミカン科に属する 3 属 (Citrus, Fortunella, Poncirus）の果皮（81 種）を n-hexane, $99 \% \mathrm{EtOH}$ で抽出した。 得られたエキスを EBV-EA 活性化抑 制試験に付し，その効果を検討した結果，メキシカ ンライム (C. aurantifolia), シャデンユ (C. grandis cv. Shytian you), ナツダイダイ, イヨ, 森田 ネーブル (C. sinensis OSBECK)，シュンコウカン (C. shunkokan Hort. ex TANAKA), スダチ $(C$. sudachi Hort. ex SHIRAI), クネンボ ( $C$. nobilis Lour. var Kunep), ヤツシロ (C. yatsushiro Hort. ex TANAKA)，ケラジ(C. keraji Hort. ex TANAKA), キノクニ, シイクワサー (C. depressa HAYATA), コウジ (C. leiocarpa Hort. ex TANAKA)，ネイハキ ンカン (Fortunella crassifolia SwINGLE)，ナガキ ンカン (F. margarita SwINGLE), カラタチ (Poncirus trifoliata RAFIN.) のヘキサンエキスが $100 \mu \mathrm{g}$ $/ \mathrm{ml}$ 濃度で $100 \%, 10 \mu \mathrm{g} / \mathrm{ml}$ 濃度で $60 \%$ 以上の EBV 活性化抑制作用を示した。 ${ }^{42}$ 特にメキシカン ライム, ナツダイダイ, スダチ, ヤツシロ, キノク ニのヘキサンエキスは $1 \mu \mathrm{g} / \mathrm{ml}$ の低濃度でも $20 \%$
以上の抑制効果を示し，細胞生存率も $100 \mu \mathrm{g} / \mathrm{ml}$ 濃 度で $60 \%$ 以上と良好であったことから，細胞毒性 の弱い抗発がんプロモーターを含有していることが 期待された。 タヒライム，バルガモット（C. bergamia RISSO et POIT), ルミーのへキサンエキスは $100 \mu \mathrm{g} / \mathrm{ml}$ 濃度で $100 \%, 10 \mu \mathrm{g} / \mathrm{ml}$ 濃度で $80 \%$ 以上 の強い抑制効果を示したが，高濃度における細胞毒 性が強かった。しかし，低濃度でも良好な活性が認 められたことから低用量での抗発がんプロモーショ ン作用が期待される.

ヘキサン，エタノールのいずれにも高い活性值が 認められたが，へキサンエキスの方が，活性の強い 傾向が認められたので，活性成分は低極性部に存在 すると推定した。

そこで比較的強い活性が認められた品種のうち, 8 種 [タヒチライム, ベルガモット，ルミー，グ レープフルーツ， キヌカワ（C. glaberrima Hort. ex TANAKA), ナツダイダイ, バレンシアオレンジ, オオベニ（C. tangerina Hort. ex TANAKA）] のエキ スを調製・分画し，得られたフラクションを EBV 活性化抑制試験に付して活性成分の分布を検討し た。シリカゲルを使用したカラムクロマト又は分取 薄層クロマト（diisopropylether で展開）を用い, $\mathrm{Rf}$ が 0.7 以上， 0.7 未満一 0.5 以上， 0.4 未満に分画 した。活性試験の結果， Rf 值が 0.5 付近のゾーン に強い活性が見られ，このゾーンはUV 照射で蛍光 を発することから，活性本体をクマリンやフラボノ イドと推定した.

3-2. 果皮成分の分離果皮をアセトン抽出 し，得られたエキスを水/䣷酸エチルエステルでの 分配あるいは Diaion HP-20 カラムにより分画し た。さらにシリカゲルを用いたカラムクロマト，分 取薄層クロマトなどを繰り返してクマリン 21 種, フラボン 14 種を単離した。 特にフラボン類はカン キツ類に特徵的に多く含まれることが知られている ポリメトキシフラボンであった.

\section{3-3. 単離成分の発がん抑制効果}

3-3-1. クマリン類の抗発がんプロモーション活 性カンキツ類に含まれるクマリンでは, auraptene（AUR）（89）が EBV 活性化抑制作用を有する ことが知られており, ${ }^{40)}$ 抗発がんプロモーターとし て有望視されている。また，最近，epoxyauraptene, 5- (3,7-dimethyl-6-epoxy-2-octenyloxy ) psora- 
len, 8-geranyloxypsoralen なども EBV 活性化抑制作 用を示すことが報告されている. ${ }^{43)}$

カンキツ果皮より単離した 21 種のクマリンを EBV 活性化抑制試験に付したところ， mexoticin （91）が AURよりも強い活性を示し，その効果は $1000 \mathrm{~mol} \mathrm{ratio} / \mathrm{TPA}$ で $100 \%, 500 \mathrm{~mol}$ ratio / TPA でも約 $90 \% \mathrm{EBV}$ 活性化を抑制し, 細胞生存率も $1000 \mathrm{~mol} \mathrm{ratio} / \mathrm{TPA}$ で $60 \%$ 以上と良好であった. ${ }^{44)}$

今回の実験によって，カンキツ類に含有される抗 発がんプロモータークマリンとして注目されている AUR（89）と同等又はそれ以上の活性を示す化合 物が見出された。特に mexoticin は有望な化合物と 考えられるが，含有量が少なくin vivo 実験に進む ことができなかった（Chart 10, Table 2).

\section{3-3-2. フラボン類の活性試験}

1）抗発がんプロモーション活性ポリメトキ シフラボン類はカンキツ類に特徵的な成分であり血 小板凝集抑制，リンパ球増殖抑制，抗潰瘍，抗炎症 などの生物活性を示すことが報告されている. ${ }^{45)}$

特に,ノビレチン（NBL）（90）は抗酸化作用を
始め多くの生理作用を有し，マウス皮膚がん抑制作 用を示すことから抗発がんプロモーターとして期待 を集めている。その他のカンキツ由来のフラボノイ ドでも hesperidin（111）や diosmin（112）はラッ ト口腔，食道，大腸，膀胱発がんを抑制すること， quercetin (113), luteolin（114）も発がん抑制効果を 有することが報告されている. ${ }^{46)}$

カンキツ果皮から単離したフラボン 14 種につい て, EBV 活性化抑制試験に付して活性を検討し

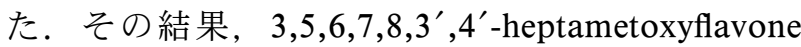
(HPT)（115）に $1000 \mathrm{~mol}$ ratio/TPA で 100\%, 500 mol ratio/TPA でも約 70\%の最も強い抑制効果が 認められ，細胞生存率も $1000 \mathrm{~mol} \mathrm{ratio/TPA} \mathrm{で} 70$ \%以上と良好であった（Chart 11, Table 3). ${ }^{47)}$

活性の強さは，置換基の数，種類及び結合位置の 違いにより，次のような傾向が認められた。 (1)メト キシ基の増加に伴って活性の強化が認められる. (2) 水酸基よりもメトキシ基を有する化合物の方が強い 活性を示す。(3)メトキシ基の結合位置による大きな 差異は認められない。しかし， 3 位にメトキシ基を<smiles>[R]c1c([R])c([R])c2oc(=O)ccc2c1[R]</smiles><smiles>[R]c1c2ccc(=O)oc2c([R])c2ccoc12</smiles>

92. $\mathrm{R}_{1}=\mathrm{R}_{2}=\mathrm{R}_{4}=\mathrm{H}, \mathrm{R}_{3}=\mathrm{OCH}_{2} \mathrm{CH}=\mathrm{C}(\mathrm{Me}) \mathrm{CH}_{2} \mathrm{CH}_{2} \mathrm{CH}(\mathrm{OH}) \mathrm{C}(\mathrm{OH})(\mathrm{Me})_{2}$ marmin 93. $\mathrm{R}_{1}=\mathrm{R}_{2}=\mathrm{H}, \mathrm{R}_{3}=\mathrm{OCH}_{2} \mathrm{CH}(\mathrm{O}) \mathrm{C}(\mathrm{Me})_{2}, \mathrm{R}_{4}=\mathrm{CH}_{2} \mathrm{COCH}(\mathrm{Me})_{2}$ isoponcimarin 94. $\mathrm{R}_{2}=\mathrm{R}_{4}=\mathrm{H}, \mathrm{R}_{3}=\mathrm{OMe}, \mathrm{R}_{1}=\mathrm{OCH}_{2} \mathrm{CH}=\mathrm{C}(\mathrm{Me}) \mathrm{CH}_{2} \mathrm{CH}_{2} \mathrm{CH}=\mathrm{C}(\mathrm{Me})_{2}$ 5-geranyloxy-7-methoxycoumarin 95. $\mathrm{R}_{1}=\mathrm{R}_{2}=\mathrm{R}_{4}=\mathrm{H}, \mathrm{R}_{3}=\mathrm{OCH}_{2} \mathrm{CH}=\mathrm{C}(\mathrm{Me}) \mathrm{CH}_{2} \mathrm{CH}_{2} \mathrm{CH}(\mathrm{OH}) \mathrm{C}\left(=\mathrm{CH}_{2}\right)(\mathrm{Me})$ 7-(6-hydroxy-3,7-dimethyl-2,7-octadienyloxy)-coumarin 96. $\mathrm{R}_{1}=\mathrm{R}_{2}=\mathrm{R}_{4}=\mathrm{H}, \mathrm{R}_{3}=\mathrm{OCH}_{2} \mathrm{CH}=\mathrm{C}(\mathrm{Me}) \mathrm{CH}_{2} \mathrm{CH}=\mathrm{CHC}(\mathrm{OH})(\mathrm{Me})_{2}$ 7-(7-hydroxy-3,7-dimethyl-2,5-octadienyloxy)-coumarin 89. $\mathrm{R}_{1}=\mathrm{R}_{2}=\mathrm{R}_{4}=\mathrm{H}, \mathrm{R}_{3}=\mathrm{OCH}_{2} \mathrm{CH}=\mathrm{C}(\mathrm{Me}) \mathrm{CH}_{2} \mathrm{CH}_{2} \mathrm{CH}=\mathrm{C}(\mathrm{Me})_{2}$ auraptene 97. $\mathrm{R}_{2}=\mathrm{R}_{4}=\mathrm{H}, \mathrm{R}_{3}=\mathrm{OMe}, \mathrm{R}_{1}=\mathrm{OCH}_{2} \mathrm{CH}=\mathrm{C}(\mathrm{Me}) \mathrm{CH}_{2} \mathrm{CH}_{2} \mathrm{CH}(\mathrm{OH}) \mathrm{C}\left(=\mathrm{CH}_{2}\right)(\mathrm{Me})$ 5-(6-hydroxy-3,7-dimethyl-2,7-octadienyloxy)-7-methoxycoumarin 98. $\mathrm{R}_{1}=\mathrm{R}_{2}=\mathrm{H}, \mathrm{R}_{3}=\mathrm{OMe}, \mathrm{R}_{4}=\mathrm{CH}_{2} \mathrm{COCH}(\mathrm{Me})_{2} \quad$ isomeranzin 99. $\mathrm{R}_{1}=\mathrm{R}_{2}=\mathrm{H}, \mathrm{R}_{3}=\mathrm{OMe}, \mathrm{R}_{4}=\mathrm{CH}_{2} \mathrm{CH}(\mathrm{OH}) \mathrm{C}(\mathrm{OH})(\mathrm{Me})_{2}$ meranzin hydrate 91. $\mathrm{R}_{2}=\mathrm{H}, \mathrm{R}_{1}=\mathrm{R}_{3}=\mathrm{OMe}, \mathrm{R}_{4}=\mathrm{CH}_{2} \mathrm{CH}(\mathrm{OH}) \mathrm{C}(\mathrm{OH})(\mathrm{Me})_{2}$ mexoticin

100. $R_{1}=R_{2}=H$ psoralen 101. $\mathbf{R}_{1}=\mathrm{OMe}, \mathrm{R}_{2}=\mathrm{H}$ bergapten 102. $R_{1}=R_{2}=O M e$ isopimpinellin 103. $\mathrm{R}_{2}=\mathrm{H}, \mathrm{R}_{1}=\mathrm{OCH}_{2} \mathrm{CH}=\mathrm{C}(\mathrm{Me}) \mathrm{CH}_{2} \mathrm{CH}_{2} \mathrm{CH}=\mathrm{C}(\mathrm{Me})_{2}$ bergamottin 104. $\mathrm{R}_{1}=\mathrm{H}, \mathrm{R}_{2}=\mathrm{OCH}_{2} \mathrm{CH}(\mathrm{OH}) \mathrm{C}(\mathrm{OH})(\mathrm{Me})_{2}$ heraclenol 10.5. $\mathrm{R}_{1}=\mathrm{OMe}, \mathrm{R}_{2}=\mathrm{OCH}_{2} \mathrm{CH}(\mathrm{OH}) \mathrm{C}(\mathrm{OH})(\mathrm{Me})_{2}$ byakangelicin 106. $\mathrm{R}_{2}=\mathrm{H}, \mathrm{R}_{1}=\mathrm{OCH}_{2} \mathrm{CH}=\mathrm{C}(\mathrm{Me})_{2} \quad$ isoimperatorin 107. $\mathrm{R}_{2}=\mathrm{H}, \mathrm{R}_{1}=\mathrm{OCH}_{2} \mathrm{CH}=\mathrm{C}(\mathrm{Me}) \mathrm{CH}_{2} \mathrm{CH}_{2} \mathrm{CH}(\mathrm{OH}) \mathrm{C}(\mathrm{OH})(\mathrm{Me})_{2}$ 5-(6,7-dihydroxy-3,7-dimethyl-2-octenyloxy)-psoralen 108. $\mathrm{R}_{2}=\mathrm{H}, \mathrm{R}_{1}=\mathrm{OCH}_{2} \mathrm{CH}(\mathrm{OH}) \mathrm{C}(\mathrm{OH})(\mathrm{Me})_{2} \quad$ oxypeucedanin hydrate 109. $\mathrm{R}_{1}=\mathrm{OMe}, \mathrm{R}_{2}=\mathrm{OCH}_{2} \mathrm{CH}=\mathrm{C}(\mathrm{Me})_{2}$ phellopterin 
Table 2. Inhibitory Effects of Treatment with Coumarin on TPA-induced EBV-EA Activations (TPA 32 pmol=100\%)

\begin{tabular}{|c|c|c|c|c|}
\hline \multirow{3}{*}{ Sample } & \multicolumn{4}{|c|}{ Concentration (mol ratio/TPA) } \\
\hline & 1000 & 500 & 100 & 10 \\
\hline & \multicolumn{4}{|c|}{$\%$ to control (\% viability) } \\
\hline $\operatorname{Marmin}(92)$ & $5.2^{a)}(60)^{b)}$ & 43.6 & 77.0 & 100 \\
\hline Isoponcimarin (93) & $0(60)$ & 42.9 & 75.8 & 97.4 \\
\hline 5-geranyloxy-7-methoxycoumarin (94) & $0(60)$ & 39.9 & 70.2 & 96.1 \\
\hline 7-(6-hydroxy-3, 7-dimethyl-2, 7-octadienyloxy)-coumarin (95) & $0(60)$ & 39.1 & 69.1 & 96.8 \\
\hline 7-(7-hydroxy-3, 7-dimethyl-2, 5-octadienyloxy)-coumarin (96) & $0(60)$ & 37.0 & 66.3 & 92.0 \\
\hline Auraptene (AUR) (89) & $0(70)$ & 38.9 & 68.0 & 95.8 \\
\hline 5-(6-hydroxy-3, 7-dimethyl-2, 7-octadienyloxy)-7-methoxycoumarin (97) & $0(60)$ & 35.0 & 66.1 & 92.1 \\
\hline Isomeranzin (98) & $0(60)$ & 25.8 & 71.8 & 92.5 \\
\hline Meranzin hydrate (99) & $0(60)$ & 14.1 & 48.2 & 81.0 \\
\hline Mexoticin (91) & $0(60)$ & 11.2 & 46.9 & 80.0 \\
\hline Psoralen (100) & $20.7(70)$ & 62.9 & 82.5 & 100 \\
\hline Bergapten (101) & $18.0(70)$ & 60.3 & 81.5 & 100 \\
\hline Isopimpinellin (102) & $14.4(60)$ & 55.7 & 77.8 & 100 \\
\hline Bergamottin (103) & $9.9(60)$ & 49.0 & 76.9 & 100 \\
\hline Heraclenol (104) & $9.7(60)$ & 46.8 & 78.3 & 100 \\
\hline Byakangelicin (105) & $8.0(60)$ & 44.3 & 75.9 & 100 \\
\hline Isoimperatorin (106) & $7.0(60)$ & 42.7 & 76.5 & 100 \\
\hline 5-(6, 7-dihydroxy-3, 7-dimethyl-2-octenyloxy) -psoralen (107) & $7.2(60)$ & 43.9 & 75.0 & 100 \\
\hline Oxypeucedanin hydrate (108) & $6.5(60)$ & 41.4 & 74.8 & 100 \\
\hline Phellopterin (109) & $4.7(60)$ & 38.2 & 70.6 & 97.8 \\
\hline Bergapten dimer (110) & $25.5(60)$ & 64.8 & 85.7 & 100 \\
\hline
\end{tabular}

a) Values present relative percentages to the positive control $(100 \%)$. b) Values in parentheses are viability percentages of Raji cells.<smiles>[R5]c1ccc(-c2oc3c([R])c([R])c([R])c([R])c3c(=O)c2[R])cc1[R]</smiles>

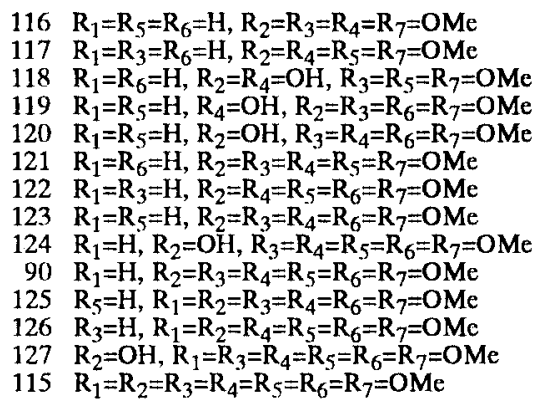

$5,6,7,4^{\prime}$-tetramethoxyflavone 6-demethoxytangeretin 5,7-dihydroxy-6,8,4'-trimethoxyflavone 7-hydroxy-5,6,3', $4^{\prime}$-tetramethoxyflavone 5-hydroxy-6,7,3',4'-tetramethoxyflavone tangeretin 6-demethoxynobiletin sinensetin

5-demethylnobiletin nobiletin $3,5,6,7,3^{\prime}, 4^{\prime}$-hexamethoxyflavone $3,5,7,8,3^{\prime}, 4^{\prime}$-hexamethoxyflavone 5-hydroxy-3,6,7,8,3',4'-hexamethoxyflavone $\mathbf{3}, \mathbf{5}, 6,7,8,3^{\prime}, \mathbf{4}^{\prime}$-heptamethoxyflavone

Chart 11

持つ化合物は，この位置にメトキシ基を持たない化 合物に比べて強い活性を示すことから，活性発現に 重要と考えられる.

今回の実験により，これまでカンキツに含まれる フラボノイドのうち, 最も有望な抗発がんプロモー ターとして注目されている NBL（90） と同等ある いはそれ以上の活性を示す化合物が見出された．特 にNBL 以上の強い活性を示した HPT は抗発がん プロモーターとして有望な化合物であることが示唆 された。 そこで，最も強い抑制作用を示した HPT
について，マウス皮膚二段階発がん抑制試験48) を行 い，その有効性を検討した。実験はマウス背部にア セトンに溶解した 7,12-dimethylbenz [a] anthracene （DMBA）を塗布してイニシエーションを行い，1 週間後から TPA を塗布してプロモーションを始め た。陽性コントロール群には，TPA を週 2 回 20 週 間塗付し続け腫瘍形成を促した。一方，実験群にお いては, DMBA でイニシエーション後 TPA 処理 1 時間前にアセトンに溶解した HPT を塗布して，コ ントロール群と同様の処理をした。TPA 塗付を開 
Table 3. Inhibitory Effects of Treatment with Flavonoids on TPA-induced EBV-EA Activations (TPA 32 pmol $=100 \%$ )

\begin{tabular}{|c|c|c|c|c|}
\hline \multirow{3}{*}{ Sample } & \multicolumn{4}{|c|}{ Concentration (mol ratio/TPA) } \\
\hline & 1000 & 500 & 100 & 10 \\
\hline & \multicolumn{4}{|c|}{$\%$ to control (\% viability) } \\
\hline $5,6,7,4^{\prime}$-tetramethoxyflavone $(116)$ & $12.7^{a)}(70)^{b)}$ & 50.6 & 78.9 & 100 \\
\hline 6-demethoxytangeretin (117) & $11.4(70)$ & 48.9 & 74.0 & 96.5 \\
\hline 5, 7-dihydroxy-6, 8, 4'-trimethoxyflavone (118) & $9.9(70)$ & 39.5 & 68.0 & 95.7 \\
\hline 7-hydroxy-5, 6, 3', 4'-tetramethoxyflavone (119) & $9.1(70)$ & 40.4 & 72.5 & 94.7 \\
\hline 5-hydroxy-6, 7, 3', 4'-tetramethoxyflavone (120) & $8.3(70)$ & 38.9 & 69.3 & 93.7 \\
\hline Tangeretin $(121)$ & $9.3(70)$ & 36.8 & 66.0 & 93.0 \\
\hline 6-demethoxynobiletin (122) & $8.5(70)$ & 40.3 & 72.1 & 95.3 \\
\hline Sinensetin (123) & $7.2(70)$ & 35.7 & 65.0 & 91.9 \\
\hline 5-demethylnobiletin (124) & $7.6(70)$ & 38.0 & 69.2 & 92.7 \\
\hline Nobiletin (NBL) (90) & $6.0(70)$ & 33.0 & 62.1 & 91.4 \\
\hline $3,5,6,7,3^{\prime}, 4^{\prime}$-hexamethoxyflavone $(125)$ & $6.5(70)$ & 43.6 & 72.1 & 95.9 \\
\hline $3,5,7,8,3^{\prime}, 4^{\prime}$-hexamethoxyflavone (126) & $5.7(70)$ & 39.3 & 68.4 & 94.6 \\
\hline 5-hydroxy-3, 6, 7, 8, 3', 4'-hexamethoxyflavone (127) & $3.6(70)$ & 32.6 & 60.4 & 90.3 \\
\hline $3,5,6,7,8,3^{\prime}, 4^{\prime}$-heptamethoxyflavone (HPT, 115) & $0(70)$ & 30.1 & 59.9 & 88.4 \\
\hline
\end{tabular}

a) Values present relative percentages to the positive control $(100 \%)$. b) Values in parentheses are viability percentages of Raji cells.

始後 20 週間, マウス 1 匹当たりの背部に発生する 腫瘍の数と腫瘍の発生したマウスの匹数を観測し, 陽性コントロール群と比較した（Fig. 1).

陽性コントロール群では，プロモーション開始後 6 週間で腫瘍が発生し，10 週後にはすべてのマウス に腫瘍が発生した。一方, HPT を塗布した群では, 8 週後に腫瘍が発生し始め発生率は 10 週後で約 25 \%,15 週後でも約 $55 \%$ であった。また，20 週後に おける平均腫瘍数は, コントロール群では約 9.5 個 に対し HPT を塗布した群では約 3 個となり, 強力 な抑制効果が認められた。さらに腫瘍の大きさにも 差異が認められた。腫瘍は直径 $1 \mathrm{~mm}$ 以上のものを 記録したが， HPT を塗布したグループのマウスに 発現した腫瘍の大きさは，コントロール群のマウス のものに比べて明らかに小さいことが確認された.

以上の結果から HPT は in vivoにおいても有意な 抗発がんプロモーション作用を有することが明らか となった。

2）NO 産生抑制試験ラジカルの1つである nitric oxide（NO）は内皮由来弛緩因子として同定 され, 血圧の調節, 血小板凝集, 好中球の活性化, 神経の可塑性, 細胞のアポトーシスなどに関わるこ とが報告されている。 また, NO は DNA 側鎖の切 断や塩基の脱アミノ反応などを起こし発がんイニシ エーターとしても作用することが知られている. ${ }^{49)}$
そこで, NO の発がんイニシエーション作用を利用 してNO ドナーである (土)-(E) -methyl-2-[ (E)-hydroxyimino] -5-nitro-6-methoxy-3-hexenamide (NOR 1）をイニシエーター, TPA をプロモーターとして 用い, イニシエーション段階におけるマウス皮膚二 段階発がん抑制試験 ${ }^{50)}$ を行い HPT の効果を検討し た.

NOR1 塗布の前後 2 週間に渡って, HPT 又は NBL を投与したのち, 週 2 回, 20 週間 TPA 塗 布し続けた。 TPA 処理を開始後 20 週間, マウス 1 匹当たりの背部に発生する腫瘍の数並びに腫瘍の発 生したマウスの匹数を観測し, 陽性コントロール群 と比較した。

まず，NOR1 によるイニシエーション作用を確 認するためにDMBA との比較によりその効力を検 討した. イニシエーターとして DMBA 又は NOR1 を用いた場合，次のような結果が得られた。

(1) DMBA では 6 週目, NOR1 では 7 週目に腫 瘍が発生し始め，それぞれ 10,12 週目にすべての マウスに腫瘍が発生した。

(2) 20 週後のマウス 1 匹当たりの平均腫瘍数は DMBA では約 9.5 個, NOR1 では約 8 個が発現し た.

以上のように DMBA のイニシエーション作用は NOR1のそれよりも強いことが示されたが，大き 

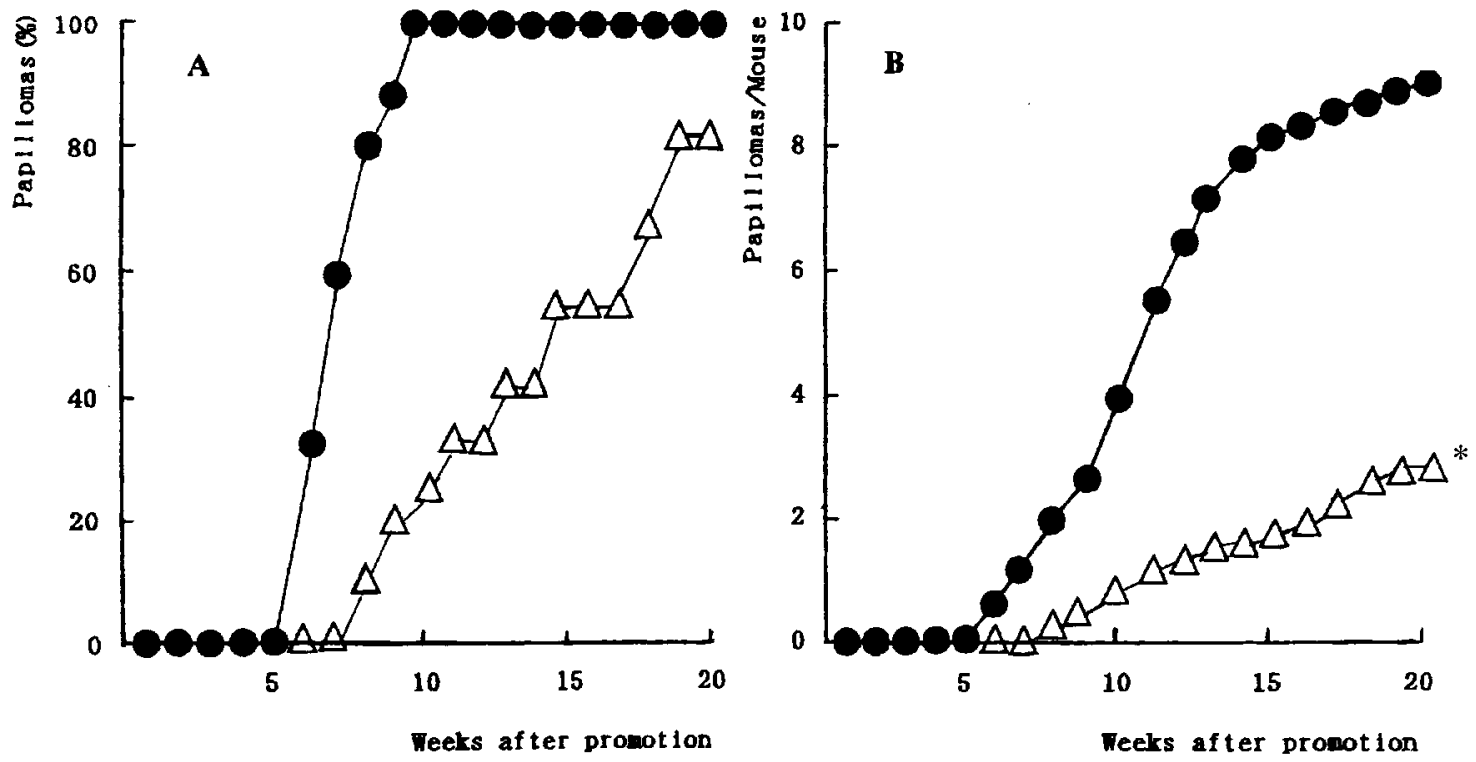

Fig. 1. Inhibition of TPA-induced Tumor Promotion by Multiple Application of 3,5,6,7,8,3', $4^{\prime}$-Heptamethoxyflavone (85 nmol) A: Percentage of mice bearing papillomas, B: Average number of papillomas per mouse.

-: control TPA alone, $\triangle$ : TPA $+85 \mathrm{nmol}$ of $3,5,6,7,8,3^{\prime}, 4^{\prime}$-heptamethoxyflavone. *Statistically different from control group $(p<0.005)$.
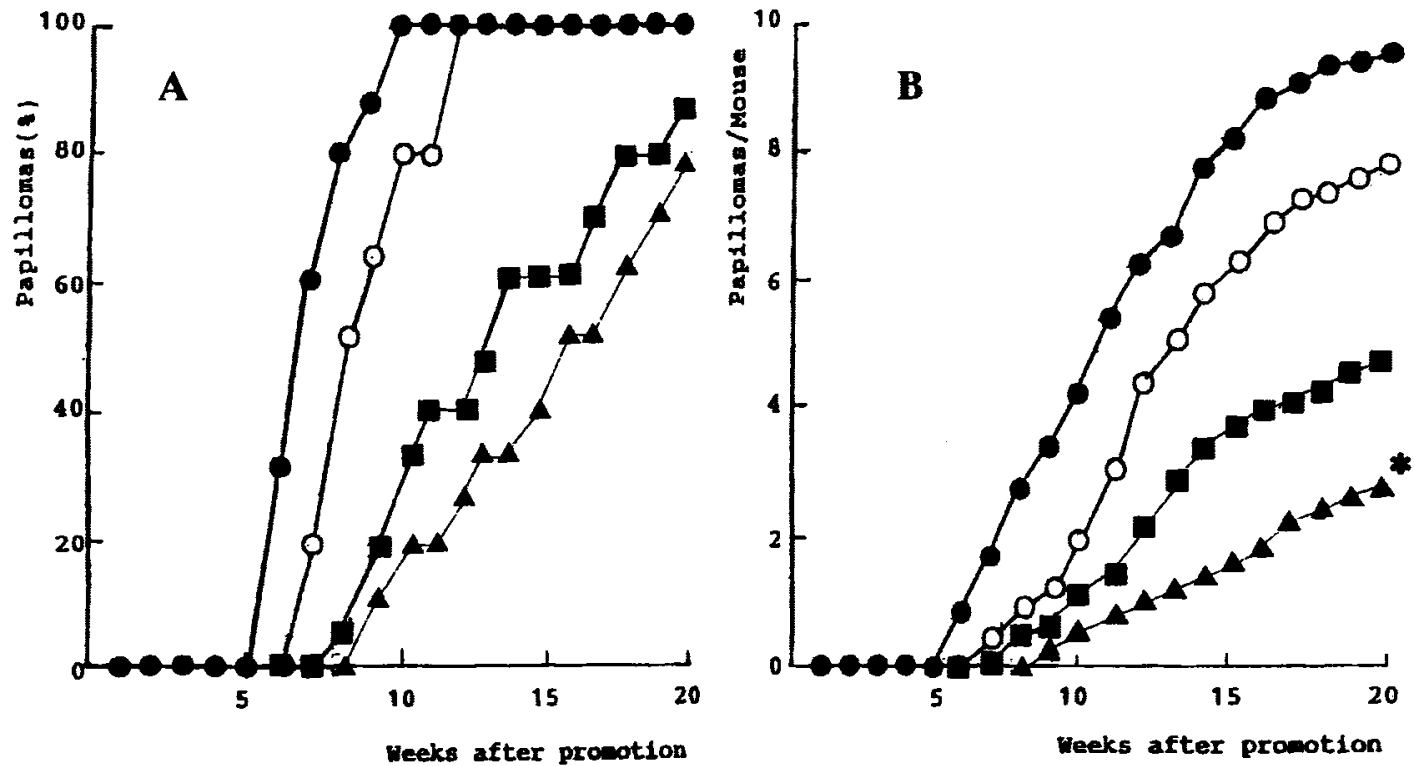

Fig. 2. Inhibition of NOR1/TPA-induced Tumor Promotion by Multiple Application of Nobiletin (NBL) and 3,5,6,7,8,3',4'-Heptamethoxyflavone (HPT)

A: Percentage of mice bearing papillomas, B: Average number of papillomas per mouse.

O: DMBA $(390 \mathrm{mmol})+$ TPA $(1.7 \mathrm{nmol})$, O: NOR1 $(390 \mathrm{nmol})+$ TPA $(1.7 \mathrm{nmol})$, $\mathbf{n}: \mathrm{NOR} 1(390 \mathrm{nmol})+0.0025 \% \mathrm{NBL}(2 \mathrm{weeks})+\mathrm{TPA}(1.7 \mathrm{nmol})$, $\Delta$ : NOR1 $(390 \mathrm{nmol})+0.0025 \%$ HPT $(2$ weeks $)+$ TPA $(1.7 \mathrm{nmol}) .{ }^{*} p<0.05$ in $t$-test between NOR1+TPA versus HPT treatment.

な差異が認められなかつたので NOR1 も DMBA 同 様にイニシエーターとしての役割を十分に果たすこ とができると判断した（Fig. 2).

NOR1 を用いた陽性コントロール群では，プロ モーション開始後 7 週間で腫瘍が発生し, 12 週後 ではすべてのマウスに腫瘍が発現した。一方，
HPT（115） 又は NBL（90）を投与した群では，そ れぞれ 9 週後, 8 週後に腫瘍が発生し始め, 発生率 は 12 週後で約 $25 \%, 40 \%$ であった。また， 20 週後 における平均腫瘍数は，コントロール群では約 8 個 に対し，HPT を投与した群では約 3 個，NBL を投 与した群では約 5 個となり，顕著な抑制効果が認め 
られた。 HPT, NBL 両化合物ともに良好な抑制活 性を示したが，HPT には NBL より強い活性が認 められ，本化合物のイニシエーション段階での優れ た発がん予防効果が明らかとなった。以上の結果か ら，HPT は in vivo でのマウス皮膚二段階発がん抑 制試験においても良好な結果を示し，発がんのイニ シエーション, プロモーションの両段階で抑制効果 を示すことが明らかとなった。また，HPT は NBL より有望な発がん予防物質と結論した. ${ }^{51)}$

HPT は多様な生物活性を有することが知られて いる．例えば HL-60 細胞を分化誘導し，がん細胞 の細胞毒性を高めること, ${ }^{52} \mathrm{TNF} \alpha$ の発生抑制に有

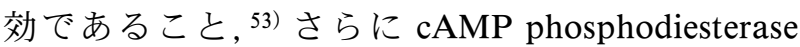
抑制活性を有することも報告されている. ${ }^{53)}$ また, HPT を始め NBL, tangeretin（TNG）（121）等のポ リメトキシフラボン含量の多いカンキツ類（クレメ ンタイン, サワーオレンジ，スイートオレンジ）の 植物オイルが真菌類に抑制効果を示すことから自然 界におけるカンキツの抵抗性の要因とも考えられて いる. ${ }^{54)}$

最近，澤田らのグループは抗がん剂の排出に関係 している P- 糖たんぱく質へのカンキツ果汁成分の 影響を検討した結果，NBL や tangeretin（121）な どが P- 糖たんぱく質を阻害することを明らかにし

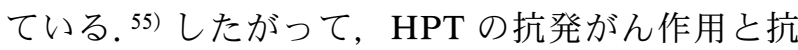
がん剂排出阻害作用を組み合わせることができれ ば，新しい観点からのがん治療法の可能性が期待さ れる。

\section{3-4. 誘導体の合成 これまでの結果から,} HPT は発がんのイニシエーション, プロモーショ ンの 2 つの過程で抑制効果を示すことが明らかとな り，発がん予防物質として有望であることが判明し た。 その作用機序の解明などには多量の HPT が必 要であるが，天然物としては含有量が少なく，多量 入手することは困難である。また，既知の合成ス キームに従った合成は，工程が長く，総収率も低 い．そこで HPT をリード化合物として比較的簡単 な構造を持ち，活性の強い化合物の創製を試みるこ とにした。

3-4-1. フラボンエーテル類の合成 メトキシ 基の数が最も多く存在する（7 個） HPT に最も強 い抗発がんプロモーション活性が認められたことか ら，メトキシ基の増加によって活性が強化されるこ
とが明らかである。これは，フラボノイドによるラ ジカルや活性酸素の消去や捕捉作用による抗酸化作 用には，フェノール性水酸基の存在が不可欠と考え られている45)のと対照的であり，HPT の抑制作用 はラジカル産生抑制に基づくことが推測された。

デザインに当たっては，酸素官能基の数をできる だけ多くすること，脂溶性を高めることを意図し て，種々のアルキルエーテル類を合成することにし た．原料には，市販品として入手が容易であり水酸 基 5 個を有する quercetin（113） 及び morin（128） を選んだ。水酸基を種々のアルキル基（メチル，エ チル，n-プロピル，n-ブチル，アリル基）でエー テル化し，炭素鎖が伸長した誘導体を合成した (Chart 12). ${ }^{56)}$

3-4-2. 合成フラボンエーテル類の抗発がんプロ モーション活性 合成したフラボンエーテル類 10 種及びアセテート 2 種について EBV 活性化抑制 試験を行った。その結果，morin（128）及び quercetin（113）のアリル体 137 及び 138 に最も強い抑 制効果が認められた。その効果は，1000 mol ratio/ TPA で $100 \%, 500 \mathrm{~mol}$ ratio/TPA でも $80 \%$ 以上の EBV 活性化を抑制し，細胞生存率も $1000 \mathrm{~mol}$ ratio /TPA で 70\% と良好であった (Table 4).57)

構造と活性には次のような傾向が認められた。

1）メチル体 $(\mathbf{1 2 9}, \mathbf{1 3 0})$ は $1000 \mathrm{~mol} \mathrm{ratio} / \mathrm{TPA}$ で $95 \%$ 以上， $500 \mathrm{~mol} \mathrm{ratio/TPA} \mathrm{でも} 75 \%$ 以上の EBV 活性化を抑制したが，エチル，n-プロピル， n-ブチルと置換基の伸長に伴い，活性強度は低下 した。この結果は，側鎖の伸長による脂溶性の増強 はかならずしも活性の強化につながらないことを示 している。しかし，アリル体 $(137,138)$ に強い効 果が観察されたことから，ある程度の脂溶性は効果 的に働き，置換基の不飽和結合が抑制活性に関与し ているものと推測された。

2）同種の置換基を有する化合物においては, morin 誘導体（B 環 $2^{\prime}, 4^{\prime}$ 位置換体）が quercetin 誘 導体（B 環 $3^{\prime} ， 4^{\prime}$ 位置換対）と比べて若干強い抑制 効果を示したことから，酸素官能基の結合位置も活 性発現に関与するものと考えられる.

3）アセテート $(139,140)$ よりメチル体（129, 130）の方が若干活性が強いことから，エーテルを エステルに変換する形で脂溶性の増強を図っても, 活性向上には寄与せず逆にマイナス因子となりかね 

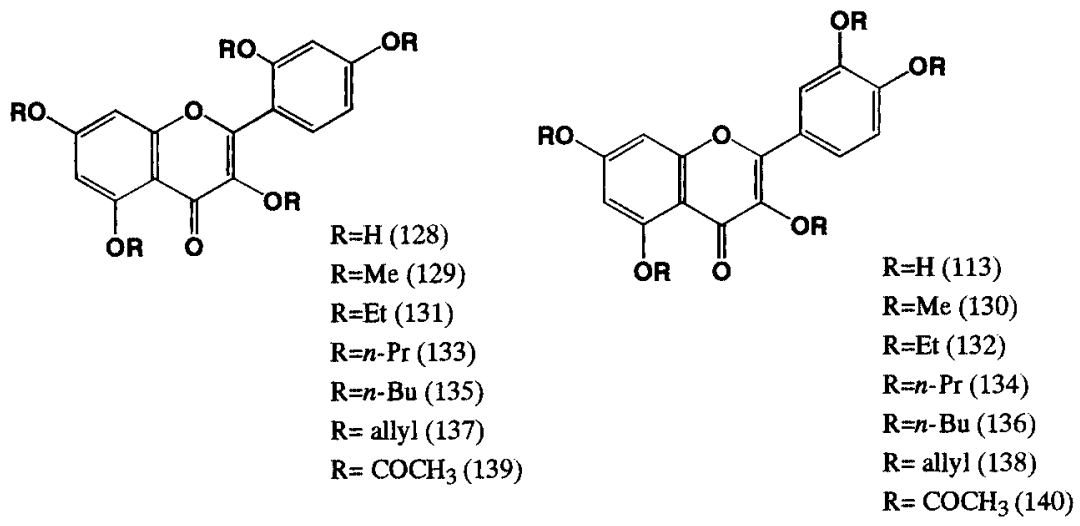

Chart 12

Table 4. Inhibitory Effects of Treatment with Flavonoid Derivatives on TPA-induced EBV-EA Activations (TPA $32 \mathrm{pmol}=100 \%$ )

\begin{tabular}{|c|c|c|c|c|}
\hline \multirow{3}{*}{ Sample } & \multicolumn{4}{|c|}{ Concentration (mol ratio/TPA) } \\
\hline & 1000 & 500 & 100 & 10 \\
\hline & \multicolumn{4}{|c|}{$\%$ to control (\% viability) } \\
\hline Morin pentamethyl ether & $4.2^{a)}(70)^{b)}$ & 30.1 & 74.0 & 96.9 \\
\hline Quercetin pentamethyl ether & $3.5(70)$ & 28.8 & 70.3 & 95.6 \\
\hline Morin pentaethyl ether & $6.3(70)$ & 38.2 & 81.4 & 100 \\
\hline Quercetin pentaethyl ether & $9.4(70)$ & 40.6 & 85.9 & 100 \\
\hline Morin pentapropyl ether & $11.8(70)$ & 45.4 & 88.0 & 100 \\
\hline Quercetin pentapropyl ether & $18.4(70)$ & 49.9 & 92.7 & 100 \\
\hline Morin pentabutyl ether & $20.7(60)$ & 52.3 & 96.4 & 100 \\
\hline Quercetin pentabutyl ether & $23.5(60)$ & 55.5 & 97.9 & 100 \\
\hline Morin pentaally ether & $0(70)$ & 15.8 & 55.0 & 81.7 \\
\hline Quercetin pentaallyl ether & $0(70)$ & 18.9 & 58.4 & 85.0 \\
\hline Morin pentaacetate & $5.7(70)$ & 35.2 & 78.4 & 100 \\
\hline Quercetin pentaacetate & $7.6(70)$ & 30.5 & 70.1 & 100 \\
\hline HPT & $0(70)$ & 30.1 & 59.9 & 88.4 \\
\hline
\end{tabular}

a) Values present relative percentages to the positive control $(100 \%)$. b) Values in parentheses are viability percentages of Raji cells.

ない.

以上の結果から活性の発現には，置換基の種類, 結合位置，そして脂溶性が関与していることが考え られる. Morin 及び quercetinのアリル体は，HPT より強い抑制効果を示したことから，抗発がんプロ モーターとしての活用が期待できる.

3-4-3. Quercetin Pentaallyl Ether（QPA）の活性 In vitro 実験において強い抑制作用が認められたア リル体のうち, quercetin pentaallyl ether (QPA) (138) について in vivo マウス皮膚二段階発がん抑 制試験を行い活性の評価を行った。 DMBAにより イニシエーションを行い， 1 週間後から TPA を塗
布してプロモーションを始めた（Fig. 3).

陽性コントロール群では，プロモーション開始後 6 週間で腫瘍が発生し，10 週後にはすべてのマウス に腫瘍が発生した。一方，QPA を塗布した群では, 9 週後に腫瘍が発生し始め, 発生率は 10 週後で 20 \%, 15 週後でも $60 \%$ であった。また，20 週後にお ける平均腫瘍率は，コントロール群では約 9 個に対 し，QPA を塗布した群は約 4 個となり，顕著な抑 制効果が認められた。この結果，QPA は in vivoに おいても有意な抗発がんプロモーション作用を有し, HPT とほぼ同等の抑制効果を持つ有望な抗発がん プロモーターであることが明らかとなった. ${ }^{57) ~ ま た, ~}$ 

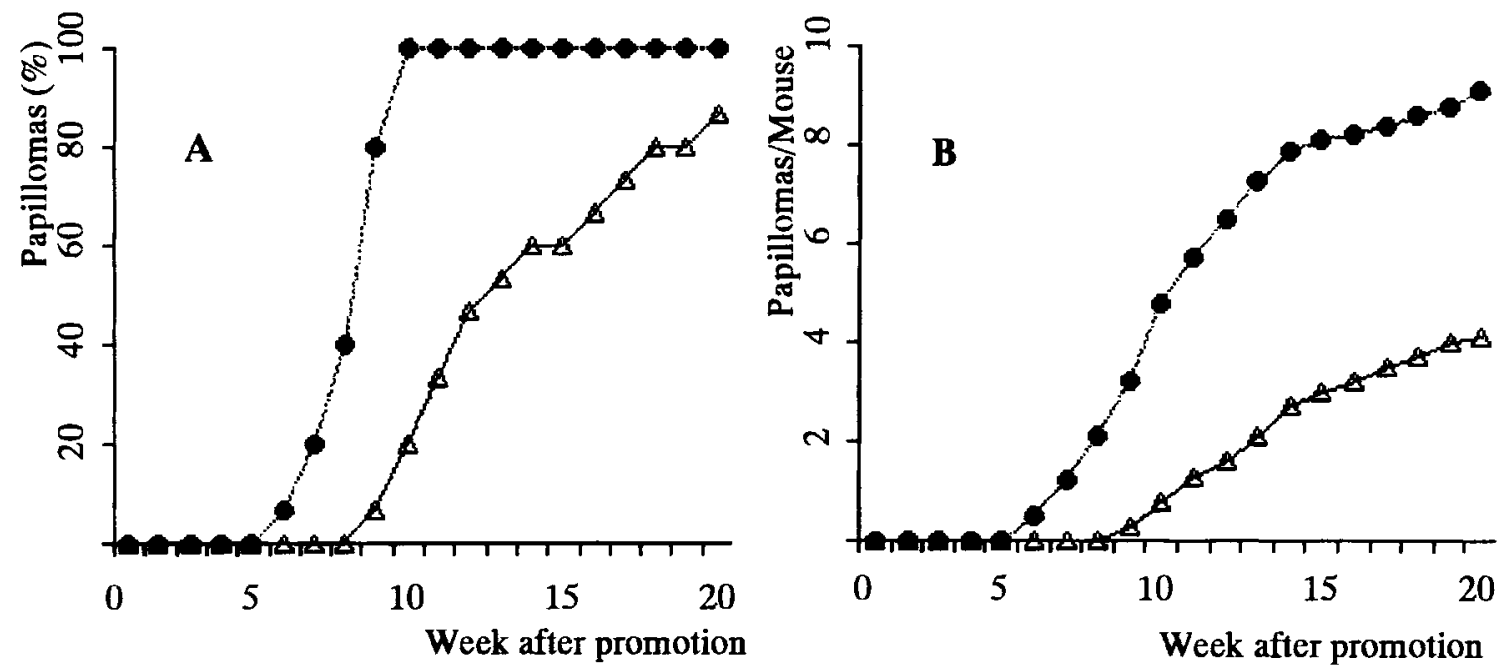

Fig. 3. Inhibition of TPA-induced Tumor Promotion by Multiple Application of Quercetin Pentaallyl Ether (85 nmol) A: Percentage of mice bearing papillomas, B: Average number of papillomas per mouse.

-: control TPA alone, $\triangle$ : TPA $+85 \mathrm{nmol}$ of quercetin pentaallyl ether.

HPT, QPA の活性の強さは, in vitro 及び in vivo において，活性の標準物質として頻用される glycyrrehetic acid (141) や curcumin (142) より強 いものであったことから，P- 糖たんぱく質との相 互作用や抗発がんプロモーターの作用機序の解明に も利用できると考えられる。

3-5. P- 糖たんぱく質阻害作用近年, 薬物と 健康食品との相互作用が話題になっている. グレー プフルーツジュースに関してもジヒドロピリジン系 カルシウム拮抗薬, シクロスポリン, テルフェナジ ン, ミダゾラムなどと併用すると, 薬物の血中濃度 の上昇をもたらすことが報告され，その原因物質の 解明が行われている. ${ }^{58)}$ ジュースに含まれているフ ラボノイドが CYP3A4 を阻害することがヒト肝ミ クロソームを用いた実験で認められ, ${ }^{59)}$ naringin (143), naringenin (144), quercetin (113) などが in vitro で阻害作用を示すことが報告されている。そ の後, 各種のフラノクマリン類が発見され阻害物質 は $6^{\prime}, 7^{\prime}$-dihydroxybergamottin (145), bergamottin （146）及びそれらの二量体であることが明らかにさ れた. ${ }^{60)}$ 最近，澤田らはオレンジジュースと抗がん 剂の相互作用を検討し，ジュースに含まれるポリメ トキシフラボンが CYP3A4 ではなく, P- 糖たんぱ く質の薬物排出作用を阻害することにより体内での 滞留時間を延長する効果のあることを明らかにし た. ${ }^{61)}$ すなわち，LLC-PK1 cell においてはビンブ ラスチンの取込は cyclosporin-A, HMF, tangeretin, nobiletin による影響はないが, MDR1 で変性した LLC-GA5-COL 300 cell では著しく増大した。 した がって，これらのポリメトキシフラボンが P- 糖た んぱく質による薬物溶出を著しく阻害することが明 らかになった。ポリメトキシフラボン類には発がん 予防効果があることを合わせ考えると, 薬物の排出 阻害に基づく抗がん剤の投与量の削減・効果の延長 など，治療法に新しい手段が加えられることにな る. そこで安価で入手が容易な原料から簡単に誘導 した QPAのP- 糖たんぱく質阻害作用を検討し た. 比較のため, その他の誘導体についても検討し た結果（Figs. 4, 5)，ブチルエーテル，quercetin, morin では効果が認められなかったが，メチル，エ チル, プロピル, アリルエーテルのすべてが K562/ ADM cell による vincristine の取込を増加させた. 特に quercetin のメチル (130)，アリルエーテル （138）及び morinのエチルエーテル（131） は

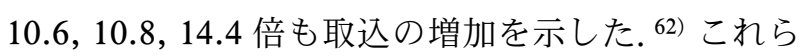
のP- 糖タンパク阻害作用は，代表的な薬物である cyclosporin A や verapamil より強いものであっ た，安価で豊富な素材から容易に合成できる QPA は抗発がんプロモーター, イニシエーターであると ともに P- 糖タンパク質の阻害作用を示すことから 「がんの化学療法」の薬物として有力な候補である ことが明らかとなった。

4. おわりに

本研究を遂行するにあたり, 終始有益な御指導・ 
(A) $\mathrm{K} 562$

(B) K562/ADM

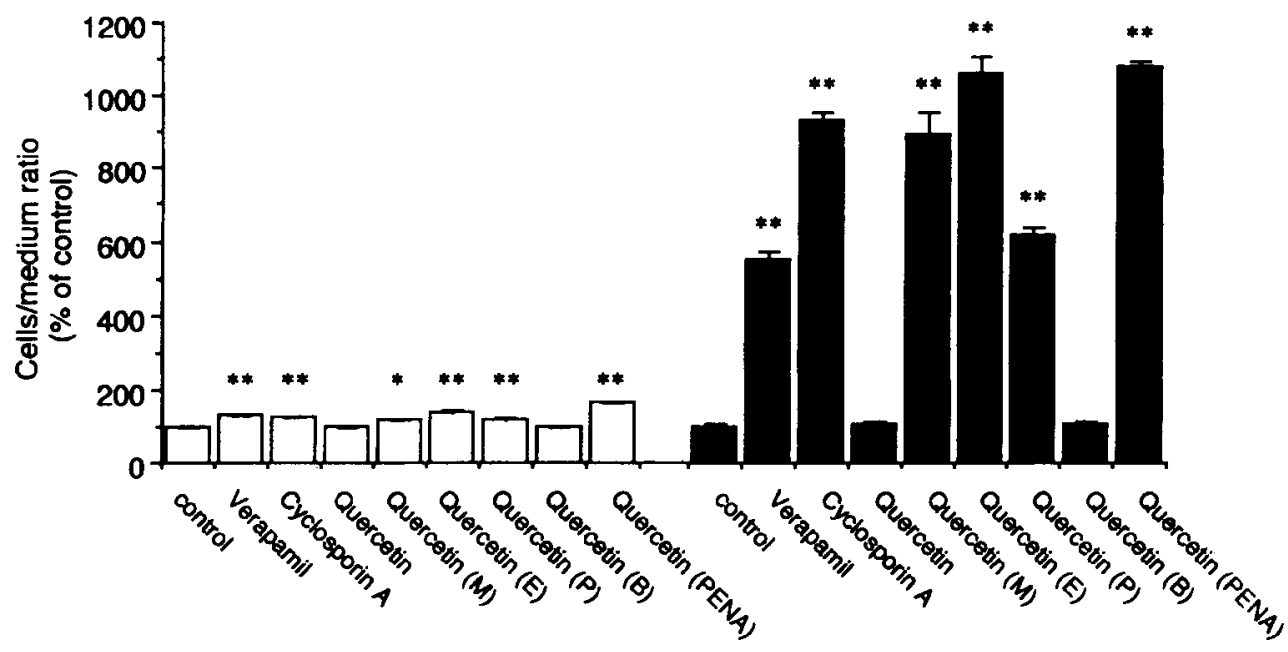

Fig. 4. Effects of $20 \mu \mathrm{M}$ Quercetin and its derivatives on the Uptake of $\left[{ }^{3} \mathrm{H}\right]$ Vincristine by (A) K562 and (B) K562/ADM Cells Each bar represents the mean S.E. from four experiments. Significant differences from the control were determined by ANOVA followed by Duncan's test $\left({ }^{*} \mathrm{p}<0.05,{ }^{* *} \mathrm{p}<0.01\right)$.

(A) K562

(B) K562/ADM

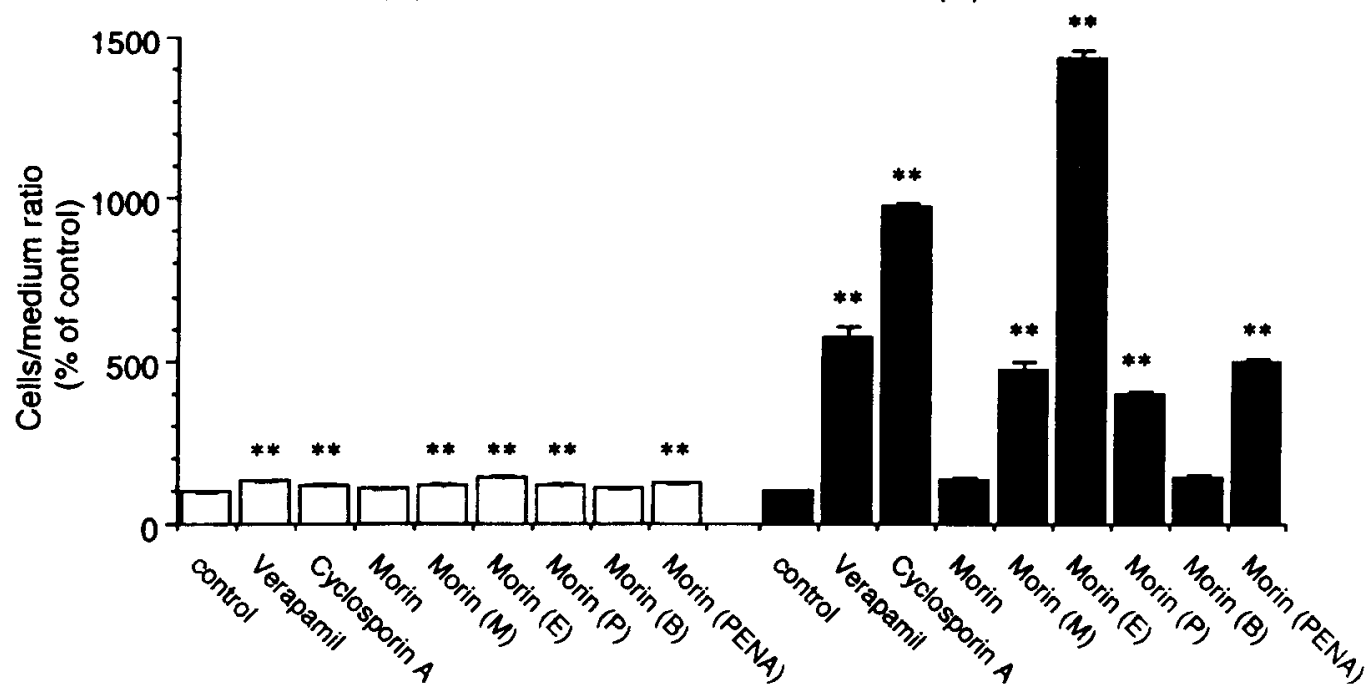

Fig. 5. Effects of $20 \mu \mathrm{M}$ Morin and its Derivatives on the Uptake of $\left[{ }^{3} \mathrm{H}\right]$ Vincristine by (A) K562 and (B) K562/ADM Cells Each bar represents the mean S.E. from four experiments. Significant differences from the control were determined by ANOVA followed by Duncan's test $(* * \mathrm{p}<0.01)$.

御鞭撻を賜りました名城大学薬学部 古川 宏教授 に厚く御礼申し上げます。また，次の方々に大変な 御援助を頂きました。名城大学薬学部 井藤千裕博 士 : 種々の機器測定と解析, 京都府立医科大学 西 野輔翼教授, 徳田春邦博士, 九州大学薬学研究院 澤田康文教授，大谷寿一博士：生物活性の測定，徳 島文理大学薬学部 浅川義範教授, 橋本敏弘博士,

Duke 大学 A. T. McPhail 教授, 名古屋市立大学 薬学部 畑野研一郎博士 : X 線結晶解析, 農林水
産省果樹試験場 (現 独立行政法人カンキツ研究部) 矢野昌充博士，大村三男博士：植物資料の提供. 本 研究は武庫川女子大学薬学部薬化学 II 教室におい て遂行されましたが，特に本教室に在籍されました 竹村優子博士, 岩瀬由紀子博士の御尽力に感謝致し ますとともに，引用文献に挙げました卒論生の方々 の御協力に感謝致します。 


\section{REFERENCES}

1) Ito Y., Yanase S., Fujita J., Harayama T., Takashima M., Imanaka H., Cancer Lett., 13, 29-37 (1981) .

2) Henle G., Henle W., J. Bacteriol., 91, 12481256 (1966).

3) Ju-ichi M., Takemura Y., Okano M., Fukamiya N., Ito C., Furukawa H., Heterocycles, 32, 1189-1193 (1991).

4) Ikeda S., Takemura Y., Ju-ichi M., Ito C., Furukawa H., Heterocycles, 48, 999-1002 (1998).

5) Takemura Y., Nakata T., Ju-ichi M., Okano M., Fukamiya N., Ito C., Furukawa H., Chem. Pharm. Bull., 42, 1213-1215 (1994).

6) Ju-ichi M., Takemura Y., Azuma M., Tanaka K., Okano M., Fukamiya N., Ito C., Furukawa H., Chem. Pharm. Bull., 39, 2252-2255 (1991).

7) Ito C., Matsuoka M., Oka T., Ju-ichi M., Niwa M., Omura M., Furukawa H., Chem. Pharm. Bull., 38, 1230-1232 (1990).

8) Takemura Y., Kawaguchi H., Maki S., Ju-ichi M., Omura M., Ito C., Furukawa H., Chem. Pharm. Bull., 44, 804-809 (1996).

9) Takemura Y., Isono Y., Arima Y., Ju-ichi M., Omura M., Ito C., Furukawa H., Heterocycles, 45, 1169-1172 (1997).

10) Ito C., Ju-ichi M., Inoue M., Muraguchi M., Mizuno T., Tanahashi S., Omura M., McPhail D. R., McPhail A. T., Furukawa H., Chem. Pharm. Bull., 37, 1957-1959 (1989).

11) Ito C., Mizuno T., Tanahashi S., Furukawa H., Ju-ichi M., Inoue M., Muraguchi M., Omura M., McPhail A. T., Chem. Pharm. Bull., 38, 2102-2107 (1990).

12) Takemura Y., Ju-ichi M., Hatano K., Ito C., Furukawa H., Chem. Pharm. Bull., 42, 997998 (1994).

13) Takemura Y., Ju-ichi M., Hatano K., Ito C., Furukawa H., Chem. Pharm. Bull., 42, 24362440 (1994).

14） Takemura Y., Nakata T., Uchida H., Ju-ichi M., Hatano K., Ito C., Furukawa H., Chem. Pharm. Bull., 41, 2061-2062 (1993).

15) Ju-ichi M., Takemura Y., Okano M., Fukamiya N., Hatano K., Ito C., Furukawa H., Chem. Pharm. Bull., 44, 11-14 (1996) .
16) Takemura Y., Ju-ichi M., Nakagawa K., Omura M., Furukawa H., Chem. Pharm. Bull., 41, 73-76 (1993).

17) Ito C., Ono T., Takemura Y., Nakata N., Ten H., Ju-ichi M., Okano M., Fukamiya N., Furukawa H., Chem. Pharm. Bull., 41, 13021304 (1993).

18) Ito C., Nakagawa M., Inoue M., Takemura Y., Ju-ichi M., Omura M., Furukawa H., Chem. Pharm. Bull., 41, 1657-1658 (1993).

19) Takemura Y., Inoue M., Kawaguchi H., Juichi M., Hashimoto T., Kan Y., Takaoka S., Asakawa Y., Omura M., Ito C., Furukawa H., Chem. Pharm. Bull., 42, 1548-1549 (1994) .

20) Takemura Y., Matsushita Y., Nagareya N., Abe M., Takaya J., Ju-ichi M., Hashimoto T., Kan Y., Takaoka S., Asakawa Y., Omura M., Ito C., Furukawa H., Chem. Pharm. Bull., 43, 1340-1345 (1995).

21) Ju-ichi M., Takemura Y., Nagareya N., Omura M., Ito C., Furukawa H., Heterocycles, 42, 237-240 (1996).

22) Takemura Y., Ju-ichi M., Omura M., Ito C., Furukawa H., Heterocycles, 51, 851-855 (1999) .

23) Takemura Y., Wada M., Ju-ichi M., Ito C., Furukawa H., Chem. Pharm. Bull., 46, 693696 (1998).

24) Ju-ichi M., Inoue M., Kajiura I., Omura M., Ito C., Furukawa H., Chem. Pharm. Bull., 36, 3202-3205 (1988).

25) Furukawa H., Ito C., Mizuno T., Ju-ichi M., Inoue M., Kajiura I., Omura M., J. Chem. Soc., Perkin Trans 1, 1990, 1593-1599.

26) Ito C., Tanahashi S., Tani Y., Ju-ichi M., Omura M., Furukawa H., Chem. Pharm. Bull., 38, 2586-2588 (1990).

27) Takemura Y., Isono Y., Arima Y., Ju-ichi M., Ito C., Furukawa H., Heterocycles, 34, 23632372 (1992).

28) Takemura Y., Ju-ichi M., Omura M., Haruna M., Ito C., Furukawa H., Heterocycles, 38, 1937-1942 (1994).

29) Takemura Y., Maki S., Ju-ichi M., Omura M., Ito C., Furukawa H., Heterocycles, 36, 675-680 (1993).

30) Takemura Y., Kurozumi T., Ju-ichi M., Okano M., Fukamiya N., Ito C., Ono T., Furuka- 
wa H., Chem. Pharm. Bull., 41, 1757-1759 (1993).

31) Takemura Y., Kuwahara J., Ju-ichi M., Omura M., Ito C., Furukawa H., Heterocycles, 45, 1411-1416 (1997).

32) Takemura Y., Takaya J., Okamura Y., Atarashi T., Nagareya N., Ju-ichi M., Omura M., Ito C., Furukawa H., Chem. Pharm. Bull., 46, 1518-1521 (1998).

33) Takemura Y., Abe M., Ju-ichi M., Ito C., Hatano K., Omura M., Furukawa H., Chem. Pharm. Bull., 41, 406-407 (1993).

34) McPhail A. T., Ju-ichi M., Fujitani Y., Inoue M., Wu T.-S., Furukawa H., Tetrahedron Lett., 27, 3271-3272 (1985).

35) Ito C., Tanahashi S., Fujiwara K., Nakagawa M., Ju-ichi M., Fujitani Y., Inoue M., McPhail A. T., Wu T.-S., Kajiura I., Omura M., Furukawa H., Chem. Pharm. Bull., 38, 1881-1885 (1990).

36) Takemura Y., Isono Y., Ju-ichi M., Omura M., Ito C., Furukawa H., Chem. Pharm. Bull., 41, 789-790 (1993).

37) Berenblum I., J. Pathol. Bacteriol., 32, 425 (1929).

38) Takemura Y., Ju-ichi M., Ito C., Furukawa H., Tokuda H., Planta Med., 61, 366-367 (1995).

39) Nishino H., Mol. Med., 33, 380-385 (1996).

40) Murakami A., Kuki W., Takahashi Y., Yonei H., Nakamura Y., Ohno Y., Ohigashi H., Koshimizu K., Jpn. J. Cancer Res., 88, 443452 (1997).

41) Murakami A., Nakamura Y., Torikai K., Tanaka T., Koshiba T., Koshimizu K., Kuwahara S., Takahashi Y., Ogawa K., Yano M., Tokuda H., Nishino H., Mimaki Y., Sashida Y., Kitanaka S., Ohigashi H., Cancer Res., 60, 5059-5065 (2000).

42) Iwase Y., Takemura Y., Ju-ichi M., Kawaii S., Yano M., Okuda Y., Mukainaka T., Tsuruta A., Okuda M., Takayasu J., Tokuda H., Nishino H., Cancer Lett., 139, 227-236 (1999).

43) Miyake Y., Murakami A., Sugiyama Y., Isobe M., Koshimizu K., Ohigashi H., J. Agric. Food Chem., 47, 3151-3157 (1999).

44) Iwase Y., Takemura Y., Ju-ichi M., Yano M., Tokuda H., Nishino H., presented at the 45th
Annual Meeting of The Japanese Society of Pharmacognosy, Sendai, on September, 1998. Abstract p 241.

45) Benavente-Garcia O., Castillo J., Martin F. R., Orturio A., Del Rio J. A., J. Agric. Food Chem., 45, 4505-4515 (1997).

46) Tanaka T., Sumida T., Ogawa H., Foods Food Ingredients J., 177, 43-47 (1998) .

47) Iwase Y., Takemura Y., Ju-ichi M., Ito C., Furukawa H., Kawaii S., Yano M., Mou X.Y., Takayasu J., Tokuda H., Nishino H., Cancer Lett., 154, 101-105 (2000).

48) Tokuda H., Ohigashi H., Koshimizu K., Ito Y., Cancer Lett., 33, 279-285 (1986).

49) Halliwell B., Lancet, 344, 721-724 (1994).

50) Tokuda H., Ichiishi E., Onazawa M., Yamaguchi S., Konoshima T., Takasaki M., Noshino H., “'Biology of Nitric Oxide,' Part 6, eds. by Moncada S., Tada N., Maeda H., Higgs E. A., Portland Press, London, 1998, pp. 185-186.

51) Iwase Y., Takemura Y., Ju-ichi M., Yano M., Ito C., Furukawa H., Mukainaka T., Kuchide Y., Tokuda H., Nishino H., Cancer Lett., 163, 7-9 (2001).

52) Kawaii S., Tomono Y., Katase E., Ogawa K., Yano M., Anticancer Res., 19, 1261-1270 (1999).

53) Manthey J. A., Grohmann K., Montanari A., Ash K., Manthey C. L., J. Nat. Prod., 62, 441 -444 (1999).

54) Del Rio J. A., Arcas M. C., Benavente-Garcia O., Ortuno A., J. Agric. Food Chem., 46, 4423-4428 (1998).

55) Ikegawa T., Ushigome F., Koyabu N., Morimoto S., Shoyama Y., Ohtani H., Sawada Y., Cancer Lett., 160, 21-28 (2000).

56) Ohtani H., Ikegawa T., Ju-ichi M., Iwase Y., Ito C., Furukawa H., Morimoto S., Shoyama M., Naito M., Tsuruo T., Sawada Y., presented at the 121st Annual Meeting of The Pharmaceutical Society of Japan, Sapporo, on March, 2001, Abstract 3, p 84.

57) Iwase Y., Takemura Y., Ju-ichi M., Mukainaka T., Ichiishi E., Ito C., Furukawa H., Yano M., Tokuda H., Nishino H., Cancer Lett., 173, 105-109 (2001).

58) Bailya D. G., Malcolm J., Arnold O., Spencer J. D., Br. J. Clin. Pharmacol., 46, 101-110 
(1998) .

59) Guengerich F. P., Kim D. H., Carcinogenesis, 11, 2275-2279 (1990).

60) Guo L.-Q., Taniguchi M., Xiao Y.-Q., Baba K., Ohta T., Yamazoe Y., Jpn. J. Pharmacol., 82, 122-129 (2000).

61) Takanaga H., Ohnishi A., Yamada S., Ma- tsuo H., Morimoto S., Shoyama Y., Ohtani H., Sawada Y., J. Pharmacol. Exp. Ther., 293, 230-236 (2000).

62) Ikegawa T., Ohtani H., Koyabu N., Ju-ichi M., Iwase Y., Ito C., Furukawa H., Naito M., Tsuruno T., Sawada Y., Cancer Lett., 177, 89 -93 (2002). 